\title{
The Cincinnati Arch: A Stationary Peripheral Bulge During the Late Ordovician
}

\author{
Michael C. Pope ${ }^{1}$, Steven M. Holland ${ }^{2}$, and Mark E. Patzkowsky ${ }^{3}$ \\ ${ }^{1}$ School of Earth and Environmental Sciences, Washington State University, Pullman, WA \\ 99164-2812 (E-mail: mcpope@wsu.edu) \\ ${ }^{2}$ Department of Geology, University of Georgia, Athens, GA 30602-2501 \\ ${ }^{3}$ Department of Geosciences, Pennsylvania State University, University Park, PA 16802-2714
}

Running Title: Cincinnati Arch - A Stationary Peripheral Bulge 


\section{ABSTRACT}

Shallow-water features, including peritidal carbonate complexes, tidally-influenced shoal-water facies, biostromes, and coincident subaerial unconformities on the peritidal complexes are restricted to the Cincinnati Arch during the Late Ordovician Taconic Orogeny. Persistence of these features along the Cincinnati Arch indicate this area experienced decreased subsidence relative to surrounding areas, forming the peripheral bulge within the Taconic foreland basin. These shallow-water features are surrounded on all sides by deeper water, shallow subtidal to deep subtidal facies. The Jessamine and Nashville Domes were prominent topographic highs on the arch and were the locus of shallow-water deposition and subaerial erosion, but many of these shallow-water features also occur in the subsurface between these two domes.

The shallow-water features and unconformities on the Cincinnati Arch occur in a narrow band repeatedly throughout the Late Ordovician. The width of these features is much too narrow to have formed solely by flexure of the lithosphere and their persistent formation in the same location indicates they did not form as a viscoelastic response to orogenesis. Rather the boundary between the Grenville Front and the Eastern Granite-Rhyolite Province acted as a focusing mechanism for the orogenic load stresses to the east, producing a relatively stationary peripheral bulge. A temporal and spatial change in the stratigraphy and subsidence on the Nashville and Jessamine Domes during the Edenian likely records a northward shift of loading, possibly sedimentary loading, during the Taconic Orogeny.

Keywords Peripheral bulge, foreland basin, Taconic Orogeny, flexure, stratigraphy 


\section{INTRODUCTION}

Stratigraphic modeling of foreland basins demonstrates that the regional stratigraphy in these basins reflects the interplay of sediment supply, eustasy, flexural loading from thrust sheet emplacement and possibly long-wavelength dynamic loading (Mitrovica et al., 1989; Gurnis, 1992a, b). The stratigraphic models are useful both in the forward mode, for understanding the principles underlying the stratigraphic architecture of foreland basins in general (Flemings and Jordan, 1989, 1990), and in the inverse mode, for reconstructing the shifting geographic location of thrust loads and changing eustatic sea level during the history of particular foreland basins (Quinlan and Beaumont, 1984; Beaumont et al., 1988). Studies of foreland basins have frequently emphasized the behavior of the peripheral bulge (or forebulge) over time, in particular, whether it is a static or mobile feature, and what such behavior implies about the rheology of the lithosphere and the movement of the loads that generate the foreland basin (Sinclair et al., 1991; Sinclair and Allen, 1992).

Thus, the peripheral bulge and its sedimentary record may provide insights into large-scale tectonism. For instance, the backstepping of carbonate reefs may record advancement of a thrust load where there is little record of this loading recorded in the basin itself (Dorobek, 1995; Galewsky, 1998; Galewsky et al., 1996). Additionally, the geographic position of the peripheral bulge with respect to the orogenic belt can be calculated if the peripheral bulge is modeled as being solely generated by flexure; commonly its position is dependent on the age of the continental crust being deformed (Crampton and Allen, 1995). Conversely, the location of the peripheral bulge can become relatively "fixed" along lateral lithospheric variability in the foreland (Waschbusch and Royden, 1992a, b) or when pre-existing structural weaknesses in the crust are reactivated (Dorobek et al., 1991). 
Whether the Cincinnati Arch was a positive structural feature that influenced deposition in Kentucky and Tennessee during the Late Ordovician Taconic Orogeny is contentious.

Interpretations range from the arch having little or no influence on sedimentation (Gustadt, 1958;

Weiss et al., 1965; Cressman, 1973; Weir et al., 1984), to limited uplift that affected sedimentation primarily during the Cincinnatian (Ettensohn, 1992, 1994), to geographic uplift only on the domes with an intervening saddle (Borella and Osborne, 1978). However, integration of outcrop and core data (Wilson, 1962; Hrabar et al., 1971; Mackey, 1972; Pope and Read, 1997a, b, 1998), favors uplift or decreased rates of subsidence along the Cincinnati Arch in Kentucky and Tennessee during much of the Late Ordovician and that this affected sedimentation, a view predicted by stratigraphic modeling (Quinlan and Beaumont, 1984). During this time a shallow-water carbonate platform developed on the Cincinnati Arch and was surrounded by deeper water, storm-influenced carbonate and shale (Keith, 1988a, b; Holland, 1993; Holland and Patzkowsky, 1996, 1997; Pope and Read, 1997 a, b; McLaughlin et al., 2004). This paper combines the detailed sequence stratigraphic framework of the Upper Ordovician strata of the Cincinnati Arch (Holland, 1993; Holland and Patzkowsky, 1996, 1998; Pope and Read, 1997a, b, 1998) to decipher the geographic position and depositional history of the peripheral bulge in this basin during the Taconic Orogeny. This history is compared to that predicted by several types of flexural models to gain insight into the mechanical behavior of the Appalachian foreland basin system during its initial formation.

\section{PERIPHERAL BULGE BEHAVIOR}

Models of foreland basin stratigraphy indicate that peripheral bulge behavior is controlled by several factors, including whether the lithosphere displays an elastic or a viscoelastic response, whether the lithosphere is mechanically continuous or broken, and whether the locations of loads 
are relatively static or mobile. The lithosphere may deform under a load in two distinct modes, depending on whether the lithosphere is modeled as a thin sheet of elastic or viscoelastic material overlying an asthenosphere modeled as an inviscid fluid. In elastic models (Fig. 1), the foreland basin adjacent to the thrust load undergoes immediate subsidence proportional to the mass of the load, with the amount of subsidence decreasing exponentially with distance (Nádai, 1963). Distal areas experience broad, but minor uplift on the peripheral bulge. For an elastic plate, the amount of uplift or subsidence at any location will change over time only if the distribution or magnitude of the load changes. In contrast, the uplift or subsidence at any location will change for a viscoelastic plate even if the distribution or magnitude of the load does not change. For a viscoelastic rheology (Fig. 1), the plate will deform initially as if it were elastic, but over time it will behave as if it were a weaker elastic plate. In effect, this will cause the basin to deepen and narrow, with the peripheral bulge becoming higher and narrower, while moving towards the thrust load.

In both of these cases, the location of the peripheral bulge will shift if the location of loading shifts. For example, in the case of a peripheral foreland basin, in which the edge of a continent undergoes attempted subduction, such as the modern-day Persian Gulf, the location of loading shifts considerably as the continent approaches the subduction zone (Jacobi, 1981). Relative to a fixed point on the continental interior, the location of loading initially lies over the adjacent, attached oceanic lithosphere. As the continent approaches the subduction zone, the location of loading moves progressively toward this fixed point. Ultimately, the loading takes place at the edge of the continental lithosphere, before subduction is aborted, owing to the buoyancy of continental lithosphere. As a result, the forebulge migrates from the oceanic lithosphere across the edge of the continent to the interior of the continent. In the case of a retroarc foreland basin, 
located on the craton side of a volcanic arc, such as in the Precordillera of Argentina or the western interior basin of North America, thrust-sheet motion is limited to a relatively defined area of shortening (Allen and Allen, 2005). As a result, the peripheral bulge experiences less overall motion towards the craton. Additionally, if the lithosphere beneath the foreland basin varies laterally in its rigidity, the position of the peripheral bulge may become "fixed" for extended periods of time (Grotzinger and Royden, 1990; Waschbusch and Royden, 1992a, b). In such cases, the peripheral bulge may appear as a stationary feature within the foreland as the basin continues to deepen both cratonward of the peripheral bulge and in the foredeep (Fig. 1).

\section{SCALING CONSIDERATIONS}

Although peripheral bulges frequently are depicted in schematic figures as topographically prominent features, flexural modeling indicates that they are actually rather subtle. In particular, peripheral bulges are commonly depicted as too tall relative to the depth of the basin, as too narrow relative to the width of the basin, and consequently, with slopes that are too steep. The theory of bending of flat, thin plates offers predictions about the scaling of peripheral bulges. For an infinite elastic slab deformed by a line load (Nádai, 1963), the vertical deflection (w) at any distance (x) from the load is

$$
w=w_{0} e^{-L x[\cos (L x)+\sin (L z)]}
$$

where $\mathrm{w}_{\mathrm{o}}$ is the vertical displacement at the load, that is, the maximum vertical displacement and $\mathrm{L}$ is the flexural parameter, equal to

$$
L=\left(\frac{\left(\rho_{m}-\rho_{f}\right) g}{4 D}\right)^{\frac{1}{2}}
$$

where $\rho_{m}$ is the density of the asthenosphere, $\rho_{f}$ is the density of the basin fill, $g$ is gravitational acceleration and $\mathrm{D}$ is flexural rigidity. 
Based on this equation, the width of the foreland basin ( width $_{\text {basin }}$ ), that is, the distance from the load to the leading edge of the peripheral bulge, is

$$
\text { width } h_{\text {tasin }}=\frac{3 \pi}{4 L}
$$

Depending on flexural rigidity and whether the basin is filled with air, water, or sediment, the width of the basin may range from 44 to $1087 \mathrm{~km}$ (Table 1). Given the values of flexural rigidity most commonly reported (Allen \& Allen, 2005), basin widths of 100-300 km are typical for most sediment-filled foreland basins.

For elastic plates, peripheral bulges should be approximately one-third wider $\left(\mathrm{W}_{\text {bulge }}\right)$ than their associated foreland basin:

$$
\text { widthbulge }=\frac{\pi}{L}
$$

Given typical values of flexural rigidity, peripheral bulges associated with sediment-filled basins should be 130-390 km wide (Table 1). The height of a peripheral bulge should scale linearly with the maximum amount of subsidence in the basin (that is, subsidence at the load), regardless of the type of fill in the basin:

$$
\frac{w}{w_{0}}=-e^{-\pi}=.0432
$$

In other words, uplift on the bulge should be approximately $4 \%$ of the subsidence in the basin. For a 1000-m deep flexure, this translates into only $40 \mathrm{~m}$ of uplift. Because the width of the peripheral bulge is likely to be greater than a hundred kilometers, slopes on the flanks of the peripheral bulge will be negligible (less than $0.1^{\circ}$ ).

Distal to the peripheral bulge is an area of minor subsidence generated by flexure, sometimes called the back-bulge basin (Decelles and Giles, 1996). The amount of subsidence in this basin is related to the amount of subsidence at the load by the relationship: 


$$
\frac{w}{w_{0}}=e^{-2 \pi}=0.00187
$$

which is less than $0.2 \%$ of the subsidence at the load. For a $1000-\mathrm{m}$ deep flexure, this translates into a mere $2 \mathrm{~m}$ of subsidence. So, although sedimentary basins commonly are developed on the distal side of the peripheral bulge, it is unlikely that their origin is solely or even primarily driven by flexure related to thrust loading.

\section{THE CINCINNATI ARCH AND APPALACHIAN FORELAND BASIN}

The Cincinnati Arch is interpreted to be the peripheral bulge of the Appalachian foreland basin, which formed by collision of Laurentia with a magmatic arc (Quinlan and Beaumont, 1984; Ettensohn, 1992). The Jessamine and Nashville Domes on the Cincinnati Arch are further interpreted to have formed from overlapping peripheral bulges, generated by orogenic and sedimentary loading in the Appalachian foreland basin and by sedimentary loading in the intracratonic Michigan and Illinois Basins (Quinlan and Beaumont, 1984; Fig. 2). The Middle to Upper Ordovician records the foundering of the Cambrian-Early Ordovician passive margin (Knox Group) of eastern North America (Read, 1989). This attempted subduction of the eastern margin of Laurentia under a volcanic arc/accretionary wedge complex (Rodgers, 1971; Drake et al., 1989) created a westward-migrating peripheral bulge that produced the regional Knox unconformity and a foreland basin extending from Alabama to Newfoundland (Jacobi, 1981; Mussman and Read, 1986; Lash, 1988). The global correlation of the Knox unconformity overlapping with the Sauk-Tippecanoe boundary (Sloss, 1963) also points to a eustatic role in its generation. The proximal foredeep was bordered on the east by tectonic highlands that served as the principal siliciclastic source to the region for the remainder of the Ordovician. The western side of this foredeep passed into a shallow carbonate ramp developed over the Cincinnati Arch (Fig. 2). Major structural elements associated with this arch were the Nashville and Jessamine 
Domes on the crest, the Sebree trough on the western side and border faults of the Rome trough on the eastern side (Borella and Osborne, 1978; Weir et al., 1984; Cable and Beardsley, 1984; Diecchio, 1993; Kolata et al., 2001).

The Taconic foreland basin in the central and southern Appalachians experienced its earliest development during the Late Ordovician, and its history commonly is subdivided into two distinct phases (Fig. 3). The first phase, known as the Blountian (W-b to M4 sequences), began in the latest Llanvirn to earliest Caradoc and its depocenter was in eastern Tennessee (Shanmugam and Walker, 1980, 1982; Shanmugam and Lash, 1982; Ettensohn, 1994). The second phase, known as the Taconic (M5-C6 sequences), began in the middle to late Caradoc and its depocenter was primarily in eastern Pennsylvania and northern Virginia (Ettensohn, 1994). Each of these phases produced a distinctive $2^{\text {nd }}$-order (10-15 m.y. duration) depositional sequence, characterized by pronounced rapid deepening in the foredeep followed by prolonged shallowing and progradation on the adjacent shallow-water carbonate ramp (Rodgers, 1971).

The Blountian phase (Fig. 3) records the development of the rapidly subsiding Sevier foredeep in Alabama, Georgia, Tennessee and Virginia, which was subsequently filled with a thick turbidite and deltaic package (Shanmugam and Walker, 1980, 1982; Shanmugam and Lash, 1982; Ettensohn, 1991, 1994). These deep-water facies pass westwards and upramp into midramp facies of the Chickamauga Group in Tennessee and coeval limestone units in Virginia (Ruppel and Walker, 1984; Read, 1980; Pope and Read, 1998). Farther to the west along the Cincinnati Arch, peritidal carbonates of the High Bridge and Stones River Groups accumulated under humid conditions on a nearly flat, muddy carbonate ramp in Kentucky, Virginia and Tennessee (Cressman and Noger, 1976; Pope and Read, 1998; Holland and Patzkowsky, 1996, 1997). 
The Taconic phase (Fig. 3) is characterized by the Martinsburg foredeep, best developed in northern Virginia, eastern Maryland and eastern Pennsylvania (McBride, 1962; Read, 1989; Lash, 1988; Ettensohn, 1991). Similar to the Sevier foredeep, the Martinsburg foredeep was filled with a thick turbidite to deltaic package. These coarse siliciclastic sediments prograded westward, culminating in the Queenston Delta (Kreisa, 1981; Dennison, 1976; Diecchio, 1993). To the west, the foredeep passed updip onto a mixed carbonate-siliciclastic ramp developed over the Cincinnati Arch. These Taconic phase rocks along the Cincinnati Arch record a fundamental change in sedimentation style from relatively pure peritidal carbonates deposited in warm waters (Stones River and High Bridge Groups), to cool, temperate water subtidal carbonates interbedded with varying amounts of shale (Brookfield, 1988; Patzkowsky and Holland, 1993; Lavoie, 1995; Pope and Read, 1998). Relatively pure subtidal and peritidal carbonates were deposited along the crest of the Cincinnati Arch and are surrounded by interbedded carbonate and shale of the Sebree trough and Appalachian basin foredeep (Keith, 1988a). The cleaner carbonate facies of the Lexington Limestone in Kentucky and Nashville Group in Tennessee (Fig. 3) are laterally equivalent to the well-described Trenton facies of the northern Appalachian Basin (Keith, 1988a, b; Brett et al., 2004). Biostratigraphic evidence suggests that uppermost Ordovician (Gamachian) rocks are not preserved on the Cincinnati Arch or in the Appalachian foreland basin in Kentucky (Sweet, 1984). Such strata were likely not deposited or were eroded during the eustatic fall associated with short-lived terminal Ordovician glaciation (Dennison, 1976; Brenchley et al., 1994). Uppermost Ordovician siliciclastics do occur in Virginia and Tennessee (Dorsch et al., 1993) and in the Queenston delta farther north (Dennison, 1976). 


\section{EVIDENCE OF PERIPHERAL BULGE POSITION}

Several lines of evidence suggest that the Cincinnati Arch was a persistent and relatively fixed site of shallow-water deposition throughout the Late Ordovician. In particular, the distribution of peritidal facies, shoal-water facies, buildups and unconformities provide evidence that the Cincinnati Arch was a shallow-water to emergent feature throughout most of the Upper Ordovician.

\section{Peritidal Facies}

Peritidal facies are consistently associated with the crest of the Cincinnati Arch, particularly the Jessamine and Nashville Domes in the Upper Ordovician.

\section{Blountian Phase}

On the Jessamine Dome in Kentucky, the basal unit of the Blountian phase is the Wells Creek Formation, a locally sandy dolostone deposited in a peritidal setting. The bulk of the overlying High Bridge Group consists predominantly of intensely bioturbated shallow subtidal to intertidal limestone (Camp Nelson and Tyrone Limestones) and lesser amounts of dolostone (Oregon Formation; Cressman and Noger, 1976; Kuhnhenn and Haney, 1986; Pope and Read, 1998). Parasequences in the High Bridge Group commonly consist of thin, intraclastic packstone bases that grade upward into pellet packstone. This unit is in turn overlain by skeletal/pelletal wackestone/mudstone capped by fenestral mudstone (Pope and Read, 1998). Most of these parasequences are difficult to trace laterally and likely formed by autocyclic processes (Ginsburg, 1971; Pratt and James, 1986).

The Oregon Formation, a thin, diagenetic unit of peritidal dolostone occurs in a roughly semi-circular region $\left(\sim 1000 \mathrm{~km}^{2}\right)$ over the Jessamine Dome (Fig. 4) on the Cincinnati Arch within the otherwise limestone-rich High Bridge Group (Wolcott et al., 1972; Cressman and 
Noger, 1976; Kuhnhenn and Haney, 1986; Kuhnhenn et al., 1981; MacQuown et al., 1984). The Oregon Formation contains abundant desiccation and prism cracks, which suggest increasing aridity and emergence of the platform during this time (MacQuown et al., 1984). The dolostone is fine-grained, fabric-preservative, and likely formed by evaporative pumping on a topographically high area (Horrell, 1981; Kuhnhenn et al., 1981; Kuhnhenn and Haney, 1986) indicating this area of the arch was emergent and likely surrounded by marine waters when the dolostone formed.

On the Nashville Dome in Tennessee, peritidally capped parasequences occur in the Blountian phase in the Murfreesboro, Ridley, Lebanon, and Carters Limestones of the Stones River Group on the Nashville Dome (Fig. 3; Holland and Patzkowsky, 1998). Most of these peritidal caps are bioturbated fenestral lime mudstones, suggesting humid depositional conditions, but some, such as those at the top of the Upper Carters, consist of desiccationcracked, laminated, dolomitic mudstones, indicative of more arid conditions. The distribution of all of these tidal-flat deposits shows no clear pattern over the Nashville Dome, suggesting that the tidal flats developed as a series of isolated islands (cf. Pratt and James, 1986) rather than from a persistent localized high. However, the lack of similar coeval peritidal facies in the Sequatchie Valley to the immediate southeast of the Nashville Dome indicates that the Nashville Dome was a broad, shallow-water feature during the Blountian phase of the Taconic Orogeny.

\section{Taconic Phase}

The Lexington Limestone and Nashville Group (Fig. 5) record shallow to deep, predominantly subtidal, cool-water carbonate and shale deposition over the Cincinnati Arch (Cressman, 1973; Patzkowsky and Holland, 1993; Holland and Patzkowsky, 1996; 1997; Pope and Read, 1997 b). Peritidal facies in these units are rare and consist of bioturbated fenestral limestone. They are 
localized over the arch (Fig. 6) and pass in all directions into deeper-water facies (Hrabar et al., 1971; Mackey, 1972; Cressman, 1973; Ettensohn, 1992; Holland and Patzkowsky, 1996, 1997, 1998; Pope and Read, 1997a, b). The peritidal facies of the humid Perryville tidal-flat complex (Mackey, 1972) were best developed along a north-south line along the Cincinnati Arch, beneath a $3^{\text {rd }}$-order sequence boundary in the Lexington Limestone (Pope and Read, 1997a, 1998). This tidal-flat succession is correlative with similar facies in the Bigby-Cannon limestone (Holland and Patzkowsky, 1997). Peritidal caps in the Bigby-Cannon and Catheys are thicker and more numerous along the western side of the Nashville Dome (Wilson, 1949), suggesting that the western flank of this dome was a persistently shallow region during the M5 and M6 sequences. As waters continued to deepen during the M6 and $\mathrm{C} 1$ sequences, peritidal facies became exceedingly rare, only occurring as isolated islands within grainstone shoals on the Jessamine Dome (e.g. Devils Hollow Member of the Lexington Limestone, Cressman, 1973; Pope and Read, 1997a; Ettensohn et al., 2004) and restricted to the southern margin of the Nashville Dome in the Catheys and Inman Formations (Wilson, 1949; Holland and Patzkowsky, 1998). Peritidal facies in the Inman Formation are green dolomitic mudstones with desiccation cracks.

Peritidal facies (Tate, Terrill, Rowland, Saluda, and Preachersville Members) occur in the Cincinnatian (C2-C5) over the Jessamine Dome (Fig. 7) and nearly everywhere consist of silty laminated dolostone with abundant desiccation cracks and sparse, short vertical burrows. These peritidal facies consistently pass northwards into coeval shallow subtidal facies (Weir et al., 1984; Holland, 1993; Pope and Read, 1997b). Localization of these peritidal facies demonstrates that the Jessamine Dome in central Kentucky was a persistent shallow area throughout the Cincinnatian Series. Only in the upper Cincinnatian (C5-C6) do these peritidal facies expand northward and downramp on the Cincinnati Arch into Ohio and Indiana (Hatfield, 1968). 


\section{Shoal-water Facies}

Peloidal-skeletal grainstone shoals were commonly affected by tidal currents along the Cincinnati Arch during the Late Ordovician. These shoals separated open-marine facies from more restricted facies deposited in semi-restricted lagoons, subtidal pools or tidal flats. The facies behind the grainstone shoals are mud-rich wackestone/packstone containing abundant stromatoporoids, mollusks, ostracods and rare corals (Wilson, 1949; Mackey, 1972; Walker and Laporte, 1970; Cressman, 1973; Holland, 1993). Shoal facies consistently developed in relatively fixed positions on the Jessamine and Nashville Domes in the Late Ordovician.

\section{Blountian Phase}

On the Jessamine Dome, cross-bedded peloidal packstone/grainstone is rare, and only locally developed in the High Bridge Group. Cross-bedded carbonate sand-shoal facies developed sporadically in the Pierce, Ridley, Lebanon and Carters limestones of the Nashville Dome, and they are nearly always local in their occurrence, suggesting the presence of isolated, ephemeral skeletal to peloidal sand shoals (Holland and Patzkowsky, 1998). One exception to this pattern is the massive member of the Lebanon Limestone, which is a widespread ooid-skeletal crossbedded grainstone, which occurs over the entire Nashville Dome without systematic variations in thickness (Wilson, 1949).

\section{Taconic Phase}

On the Jessamine Dome, skeletal packstone and grainstone of the transgressive Curdsville Member of the Lexington Limestone are widespread and form a series of hardground-bounded parasequences (Pope and Read, 1997a). These grainstones are rich in phosphate, and indicate that strong waves and tidal currents commonly affected the Jessamine Dome during this transgression. 
Tidally influenced skeletal grainstone facies of the Lexington Limestone (Fig. 6) are best developed along the axis of the Cincinnati Arch and over the Jessamine Dome (Hrabar et al., 1971; Cressman, 1973; Borella and Osborne, 1978; Pope and Read, 1997, 1998). These shoalwater facies are rich in phosphate, comprised predominantly of brachiopods, bryozoans and crinoids and commonly have herringbone cross bedding oriented to NW-SE (Hrabar et al., 1971; Pope and Read, 1997a). These grainstone shoals developed on local topographic highs over the Jessamine Dome (Hrabar et al., 1971; Cressman, 1973; Ettensohn, 1992).

The Garrard Siltstone, the coarsest siliciclastic unit along the Cincinnati Arch in the Upper Ordovician, was deposited in shallow to deep waters (Jacobs, 1986; Ettensohn et al.1986a) and is laterally equivalent to high-energy skeletal grainstones in the subsurface to the south (Pope and Read, 1997b). Bimodal paleocurrent measurements in the Garrard Siltstone suggest at least part of the Garrard Siltstone was deposited in a tidal setting. Outcrops of the Garrard Siltstone are restricted to a linear trend along the southeastern side of the Cincinnati Arch, suggesting its distribution was structurally controlled (Weir et al., 1984; Ettensohn, 1986a; Jacobs, 1986).

A belt of grainstone shoals is sporadically present during the $\mathrm{C} 3$ to $\mathrm{C} 5$ sequences on the northern flank of the Jessamine Dome, but is oriented east-west (Holland, 1993; Weir et al., 1984). These grainstones are restricted to the transgressive systems tracts of these sequences and separate restricted lagoonal mudstones and wackestones to the south (e.g., Gilbert, Sunset Members) from open-marine shallow subtidal packstones and fossiliferous mudstones to the north (e.g, Mount Auburn, Oregonia Formations). These grainstone shoals are typically approximately 1-m thick and display large-scale trough cross bedding. They are composed primarily of crinoid ossicles and highly abraded skeletal material, but are also rich in phosphate 
and are locally enriched in thick ramose, frondose and massive bryozoans, all highly abraded and bored.

On the Nashville Dome, transgressive grainstones of the Curdsville Member lying above the M4/M5 unconformity are restricted to the flanks of the Nashville Dome and correlate to a welldeveloped hardground/unconformity developed on the Stones River Group (i.e., Curdsville Island of Wilson, 1962; Holland and Patzkowsky, 1997). Like the peritidal facies, shoal facies on the Nashville Dome display a more organized pattern of distribution in the M5-C5 sequences. Cross-bedded, crinoidal to skeletal, phosphatic grainstones are a prominent feature of the BigbyCannon, Catheys, Leipers and Fernvale Formations. Although such grainstones are present locally at the base of several parasequences, they are thickest and best developed along a persistent north-south belt (Fig. 6) on the western flank of the Nashville Dome (Holland and Patzkowsky, 1998; Wilson, 1949). There, the cross beds display a strong bimodal pattern, suggesting tidal influence and the development of a tidal-bar belt (Ball, 1967) along the edge of the Sebree trough, just west of the Nashville Dome. This belt of carbonate sands passes westward into a thick package of deep subtidal storm beds and passes eastward into bioturbated shallow subtidal packstones.

\section{Buildups}

Organic buildups (generally biostromes, less commonly low-relief bioherms) are not common on the Jessamine and Nashville Domes and are rarely more than meter thick. Commonly, the organisms capable of producing organic biostromes are associated with shoal and peritidal facies and have a relatively fixed distribution in the Late Ordovician.

\section{Blountian Phase}


On the Jessamine and Nashville Domes, numerous organisms capable of constructing biostromes are present in the High Bridge and Stones River Groups. Most commonly, these include stromatoporoids and tabulate corals (favositids and tetradiids; Wilson, 1949; Patzkowsky and Holland, 1999). However, in only a few cases do they occur in concentrations dense enough to constitute biostromes. For example, small, isolated buildups developed in the Carters Limestone near the southern margin of the Nashville Dome (Alberstadt et al., 1974). These biostromes consist of tabulates, stromatoporoids and bryozoans and are up to a few meters thick. More commonly, biostrome-producing organisms are present but only sparsely distributed through shallow subtidal bioturbated wackestone and packstone facies (Cressman and Noger, 1976; Patzkowsky and Holland, 1999)

\section{Taconic Phase}

In the M5 through C6 sequences of the Jessamine and Nashville Domes, a wider array of potential biostrome-producing organisms is present than during the Blountian phase and includes chaetetids (Solenopora; see Riding, 2004), stromatoporoids, tabulates, colonial rugosans and bryozoans. Several distinct biostromes are present, but all are restricted to a few square kilometers in area or less and do not repeatedly occupy the same region. Shallow subtidal, shoal and peritidal facies also all commonly contain these potential buildup-constructors (Holland and Patzkowsky, 1998; Patzkowsky and Holland, 1999; Pope and Read, 1998; Wilson, 1949; Weir et al., 1984).

On the Jessamine Dome, the Sulphur Well Member of the Lexington Limestone is a bryozoan biostrome up to $5 \mathrm{~m}$ thick, surrounded by a grainstone shoal along the axis of the Cincinnati Arch (Cressman, 1973; Ettensohn et al., 1986b). Deposition of the Sulphur Well Member is hypothesized to be structurally controlled (Ettensohn et al., 2004). Stromatoporoids 
and chaetetids locally form biostromes in the Lexington Limestone (McLaughlin et al., 2004). Bryozoans also form small, localized biostromes in shallow subtidal facies throughout the Cincinnatian (e.g., Cuffey, 1998), but these are typically less than a meter thick and less than a few dozen square meters in area. A small patch biostrome consisting of chaetetids is present in one outcrop in the Cincinnatian near Winchester, Kentucky (Weir et al., 1984). The C5 sequence in northern Kentucky and southeastern Indiana contains a series of biostromes composed of colonial rugosans and tabulates, including the Bardstown, Kentucky "reef" (Browne, 1964), the Otter Reef Coral Bed near Richmond, Kentucky (Simmons and Oliver, 1967), and various biostromes associated with Saluda peritidal facies in southeastern Indiana (Hatfield, 1968). In most places, these biostromes are approximately one meter thick.

On the Nashville Dome, few biostromes are known from the Taconic phase. One low (50 $\mathrm{cm})$, small (100 $\mathrm{m}$ in length) biostrome composed entirely of the chaetetid Solenopora is present in the $\mathrm{C} 1$ sequence along the western flank of the Nashville Dome near Franklin, Tennessee (Holland and Patzkowsky, 1998, their fig. 11). Large domal stromatoporoids are common in grainstone-rich facies of the M5 and M6 sequences, as they are on the Jessamine Dome, and form only localized biostromes up to a meter thick. Rugosan and tabulate biostromes are absent in the Cincinnatian on the Nashville Dome, unlike the Jessamine Dome and northern Cincinnati Arch.

\section{Unconformities}

Unconformities separating $3^{\text {rd }}$-order depositional sequences record their greatest erosion or period of non-deposition on the Jessamine and Nashville Domes along the crest of the Cincinnati Arch in the Late Ordovician, and commonly pass off the arch into downdip conformities.

\section{Blountian Phase}


Regional truncation has not been documented at the M2-M4 sequence boundaries over the Jessamine Dome or the M1-M4 boundaries on the Nashville Dome, at least in part owing to a lack of marker horizons such as K-bentonites. Nonetheless, these erosional surfaces provided the material for multiple intraclastic beds at the bases of these depositional sequences (Kuhnhenn et al., 1981; Holland and Patzkowsky, 1996). Additionally, the occurrence of a laterally continuous dolostone (Oregon Formation) in this otherwise limestone dominated unit, located on the Jessamine Dome suggests this area was subaerially exposed for a protracted interval following deposition.

K-bentonite ash beds are common in the upper part of the Blountian succession and two of these beds (Deicke and Millbrig) are regionally widespread, facilitating correlations throughout the eastern midcontinent and Appalachian Basin (Haynes, 1994; Kolata et al., 1996). The Millbrig (locally known as Mud Cave or T-4) K-bentonite, which occurs immediately below the High Bridge Group-Lexington Limestone contact, is eroded over much of the Jessamine Dome and is preserved only in structural lows (Fig. 4; Haynes, 1994; Kolata et al., 1996, 1998). The erosional relief of the post-High Bridge Group unconformity (M4/M5) is localized over the Jessamine Dome on the Cincinnati Arch where up to $5 \mathrm{~m}$ of the Tyrone Limestone is missing (Cressman, 1973). Over the Jessamine Dome, the basal Lexington limestone commonly contains clasts up to $10 \mathrm{~cm}$ in diameter of Tyrone Limestone lime mudstone. This unconformity passes downramp into a correlative conformity (Pope and Read, 1997b).

Over the Nashville Dome, up to $10 \mathrm{~m}$ of the Carters Formation, including both the Deicke and Millbrig K-bentonites are locally eroded, with the amount of erosion increasing towards the western flank of the Nashville Dome (Wilson, 1962; Wilson and Stearns, 1963; Holland and Patzkowsky, 1997). However, the K-bentonites are present on the eastern flank of the dome and 
in the subsurface surrounding the dome (Haynes, 1994), indicating that erosion was limited to the topographically higher dome. Erosional fragments of the Carters Formation occur locally in the basal Hermitage Formation (Wilson, 1962; Holland and Patzkowsky, 1998).

\section{Taconic Phase}

Widespread subaerial unconformities in the Lexington Limestone developed only above the regionally developed tidal flat facies (Perryville Member-Lexington Limestone; Dove BedsNashville) on the Cincinnati Arch (Mackey, 1972; Pope and Read, 1997a,b; Holland and Patzkowsky, 1996, 1997) and pass downramp into conformable subtidal surfaces. Along the arch the unconformity above the Perryville tidal-flat facies has small karstic cavities up to 1.5 meters deep that are filled with phosphatic sand produced during the subsequent transgression (Pope and Read, 1997b). Locally developed tidal flat facies (cf. Devils Hollow Member-Lexington) show less evidence for subaerial exposure and pass laterally into phosphatic hardgrounds oftentimes capped by phosphatic grainstone.

Subaerial unconformities are more easily recognized over the Nashville Dome due in large part to the greater abundance of peritidal lime mudstones (Dove Beds) in this area (Wilson, 1962). However, the most widespread unconformity occurs at the M6 boundary and this surface is directly correlative with the unconformity above the Perryville Member in Kentucky (Holland and Patzkowsky, 1996, 1997).

$3^{\text {rd }}$-order sequence boundaries in the Cincinnatian Series (C1-C6) on the Jessamine Dome and northern Cincinnati Arch rarely display obvious evidence of differential truncation of underlying strata, in part because of an absence of marker horizons such as bentonites. The $\mathrm{C} 6$ sequence, however, is preserved only on the northern half of the Cincinnati Arch and shows a depositional pinchout to the south. This restriction to the northern arch is consistent with the 
distribution of peritidal facies in the Cincinnatian (Figs. $5 \& 7$ ), as well as the east-west orientation of the grainstone shoals in the $\mathrm{C} 2-\mathrm{C} 4$. Collectively, these features suggest a persistent northward dip of Jessamine Dome and northern Cincinnati Arch in the C2-C6 sequences, with persistently shallower conditions to the south.

On the Nashville Dome, truncation at the M4-M5 boundary, made visible by K-bentonites as in central Kentucky, reveals a strong east-west pattern of truncation, with at least $7 \mathrm{~m}$ more strata eroded at this sequence boundary in the west than the east (Holland and Patzkowsky, 1998, their figure 9). A major truncation surface is also present at the C5 sequence boundary, which displays the progressive loss of the underlying $\mathrm{C} 4, \mathrm{C} 3$ and partially the $\mathrm{C} 2$ sequences from north to south (Holland and Patzkowsky, 1998, their figure 11). This pattern, strikingly different from that seen in the M5 through C4, suggests a tectonic reconfiguration on the Nashville Dome prior to deposition of C5.

\section{EVIDENCE OF TECTONIC ACTIVITY}

Several lines of evidence, including seismites, syntectonic faulting and differential subsidence, all suggest that the Cincinnati Arch was subjected to seismic activity during the Late Ordovician.

\section{Seismites}

Several horizons of seismically induced, synsedimentary ball-and-pillow beds (seismites) occur within Upper Ordovician strata of the Jessamine Dome (Pope et al., 1997; Ettensohn et al., 2002; Jewell and Ettensohn, 2004; MacLaughlin and Brett, 2004). These seismites indicate occasional large earthquakes (Moment Magnitude 5-8) occurred in this region of the Cincinnati Arch during the Late Ordovician (Pope et al., 1997). However, whether these faults formed as a response to 
local stress or by stresses generated much farther afield in the foreland basin (e.g., Jewell and Ettensohn, 2004; McLauglin and Brett, 2004) is unclear.

Similar seismite beds occur in M5-C5 strata on the Nashville Dome (Holland and Patzkowsky, 1997). Most of these are visible in the southern half of the Nashville Dome, where individual horizons can be correlated for tens of miles from east to west. Some of these seismites are closely associated with sequence boundaries, such as at the $\mathrm{C} 5$ sequence boundary and at the Ordovician-Silurian unconformity; it is unclear if this association reflects enhanced preservation or increased seismicity (cf. McLaughlin and Brett, 2004).

\section{Faults and Structural Features}

The Jessamine Dome is a fault-bounded structure that localized the development of tidally influenced skeletal grainstones and stromatoporoid buildups in the Lexington Limestone (Ettensohn, 1992; Hrabar et al., 1971; Cressman, 1973; Pope and Read, 1995, 1997a). The Kentucky River Fault system and other unnamed faults that delineate this structure are basement features that were likely reactivated by Taconic orogenesis (Ettensohn, 1992; Ettensohn et al., 2002 and references therein). Synsedimentary growth faults are documented from the Lexington Limestone in Kentucky (Black and Haney, 1975; Pope et al., 1997a). It is not known whether fault structures are responsible for the persistent position of shoals and tidal flats on the Nashville Dome, but such consistency in their occurrence hints at the role of prior structures.

Peritidal facies of the Perryville Member of the Lexington Limestone commonly are laterally equivalent to deeper water shale that occurs in east-west trending zones, which may reflect differential subsidence perpendicular to the regional trend of the Cincinnati Arch (Mackey, 1972; Kulp, 1995; Kulp and Ettensohn, 1995; Ettensohn et al., 2002). Structurally controlled east-west 
trending troughs produce alternating topographic highs and lows along the arch with tidal flats restricted to highs and slightly deeper water channels (Mackey, 1972) occupying lows. The close association of these channels with exposed fault segments suggests these were produced by reactivation of Precambrian or earlier Paleozoic faults (Cressman, 1973; Black, 1976; Kulp, 1995; Rast and Goodman, 1995; Kulp and Ettensohn, 1995; Pope and Read, 1997a; Ettensohn et al., 2002, 2004).

The Sebree Trough is an enigmatic narrow (25-150 km wide) and elongate (600 km long) deep-water basin that formed west of the Cincinnati Arch and filled with black shale during the Chatfieldian-Richmondian (Kolata et al., 2001). The Sebree Trough is interpreted to have formed over the Precambrian-Cambrian Reelfoot rift (Kolata et al., 2001) or through the reactivation of basement structures by far-field stresses from foreland basin loading (Ettensohn et al., 2002).

\section{Subsidence History}

Backstripping was used to reconstruct the accommodation history of the Jessamine and Nashville Domes (Fig. 8; see Holland and Patzkowsky, 1998 for details on methods). Although the eustatic and tectonically driven subsidence components cannot be separated from this limited data, it is assumed that the longer term features of this accommodation history reflect tectonic subsidence, whereas the short-term features ( $<1-3$ m.y.) are thought to reflect eustasy (Holland and Patzkowsky, 1998).

Through the M6 sequence, the Jessamine and northern Nashville Domes have comparable subsidence rates, suggesting that these regions were undergoing moderate subsidence, although it is possible that this history actually reflects slow long-term eustatic rise. Beginning in the $\mathrm{C} 1$ sequence, however, the subsidence histories of these two regions began to diverge. Although 
subsidence rates on the Jessamine Dome are only slightly lower than before, those on the northern Nashville Dome underwent a four-fold decrease. This pattern of relatively faster subsidence rates to the north along the Cincinnati Arch is true even north of the Jessamine Dome, where Cincinnatian strata in southwestern Ohio and southeastern Indiana are $40 \%$ thicker than those on the Jessamine Dome. Likewise, the pattern of slower subsidence rates to the south is consistent with the erosional loss of the $\mathrm{C} 2-\mathrm{C} 4$ sequences before $\mathrm{C} 5$ deposition on the southern Nashville Dome. This change in subsidence rates is notable in that it does not coincide with the onset of the Taconic phase early in the M5, but is initiated 2-3 million years later in the Edenian Stage (C1).

These subsidence histories, combined with the lack of any long-duration unconformities suggest that the Jessamine and Nashville Domes were slowly subsiding features throughout the Late Ordovician, rather than actively uplifting features. The difficulty of disentangling eustasy and tectonic subsidence in single locations, however, does open the possibility that the Cincinnati Arch may have experienced some uplift, particularly in the northern Nashville Dome region, but that this uplift was combined with a somewhat larger rate of eustatic rise to produce a net slow positive rate of accommodation. The truncated record of the $\mathrm{C} 2-\mathrm{C} 4$ sequences on the southern Nashville Dome more strongly suggests uplift.

\section{DISCUSSION}

\section{Comparison to Flexural Models}

Based on viscoelastic and elastic modeling of foreland basin stratigraphy, a peripheral bulge should migrate towards the craton as the orogenic load advances onto the continent (Quinlan and Beaumont, 1984; Flemings and Jordan, 1989, 1990; Jordan and Flemings, 1991; Dorobek, 1995). Furthermore, viscoelastic models predict that the peripheral bulge should move toward the thrust 
load and the foredeep should deepen as loading is "relaxed". The Taconic foreland basin has been interpreted to record such a viscoelastic response to loading (Tankard, 1986; Quinlan and Beaumont, 1984; Beaumont et al., 1988; Ettensohn, 1991, 1992, 1994). However, if the Cincinnati Arch was a peripheral bulge, it appears that its position did not migrate during the Late Ordovician. Instead, it appears to have been a relatively fixed, or static, feature throughout the Taconic Orogeny. Additionally, the boundaries for many of these features (e.g., the Jessamine Dome, Sebree Trough) are fixed and clearly associated with faults (Ettensohn, 1992; Ettensohn et al., 2002; Kolata et al., 2001).

\section{Scale Issues}

The width of the preserved Taconic foreland basin is $\sim 200-300 \mathrm{~km}$, from the western edge of its thrust front to the eastern edge of the peripheral bulge (Fig. 2). Undoubtedly, the width of the Taconic foreland basin was likely larger during deposition due to subsequent shortening during thrusting, however, according to equation (4) the peripheral bulge for a basin of this width should be $\sim 250-400 \mathrm{~km}$ wide. However, all shallow water features in the Upper Ordovician along the Cincinnati Arch occur within an area less than $150 \mathrm{~km}$ in width (Figures 4, 6, and 7). Similarly, wireline-log correlations across the Taconic foreland basin from Kentucky to Virginia indicate that the zone of shallow-water sediments across the Cincinnati Arch is less than $180 \mathrm{~km}$ wide (Hohman, 1998; Pope and Read, 1997a). This suggests the Cincinnati Arch is far too narrow a feature to be a peripheral bulge formed by flexural loading of a continuous elastic or viscoelastic plate. We suggest the Cincinnati Arch is so narrow because it was forming as a response to the reactivation of basement features, where the flexural load stresses were transmitted to the same location repeatedly over a prolonged period of time (10-12 m.y.). 
The Sebree Trough also could be interpreted as a backbulge basin to the Cincinnati Arch. However, the Sebree Trough is also too narrow of a feature to be a backbulge basin, since the width of the backbulge basin should be comparable to the width of the forebulge (Turcotte and Schubert, 2002). Likewise, the extremely small amount of subsidence that could be generated from lithospheric flexure in a backbulge basin $(<0.2 \%$ of the subsidence at the load) also argues against such an origin for the deep-water Sebree Trough.

\section{Persistence of Cincinnati Arch}

The localization of peritidal and shoal-water facies, as well as buildups and unconformities in the Upper Ordovician along the Cincinnati Arch all indicate the crest of the Cincinnati Arch was a relatively high topographic feature throughout much of the Taconic Orogeny. Such topographic persistence does not necessarily imply uplift and could reflect lower subsidence rates on the domes relative to surrounding regions. The Jessamine and Nashville Domes were the most common sites of shallow-water sedimentation on the arch, which was surrounded at all times by deeper water. Additionally, while the record of sedimentation on these domes is similar, it is not identical and these variations in sedimentation and stratigraphy likely provide information about coeval tectonism and its sedimentary response.

Erosion of the High Bridge and Nashville Groups as well as the Millbrig and Deicke Kbentonites indicates the Jessamine and Nashville Domes were topographically positive features subjected to subaerial exposure and erosion prior to Taconic phase deposition on these domes. Erosion of the Deicke K-bentonite over much of the Nashville Dome area and greater amount of missing Blountian sediments indicate that this structure experienced more widespread erosion than the Jessamine Dome prior to deposition of the overlying M5 strata. 


\section{Basement Control on Location of the Cincinnati Arch}

Evidence for the persistence of the Cincinnati Arch indicates that it formed in the same location repeatedly. Peripheral bulges may not migrate, or can appear to reoccur in the same position repeatedly (Waschbusch and Royden, 1992a, b), owing to inherited structural weaknesses or heterogeneities in the underlying lithosphere (Fig. 1). In such a scenario, the weaker regions of the lithosphere bends more easily than stiffer regions, so plate bending is concentrated within the weak zone and the peripheral bulge becomes "fixed". In this case, the width of the peripheral bulge should reflect the width of the weak zone, not the flexural wavelength of the plate (Waschbusch and Royden, 1992a).

The most prominent heterogeneity in the basement along the Cincinnati Arch (Fig. 9) is the boundary between the Grenville front and the Eastern Granite-Rhyolite Province (EGRP) and the overlying East Continent Rift Basin (ECRB) that parallels the eastern limit of the Cincinnati Arch (Drazhoval et al., 1992; Van Schmus et al., 1993). The Grenville front consists of highgrade metamorphic rocks that were thrust over the calc-alkaline rocks of the EGRP and riftrelated basalts and sediments of the ECRB (Drazhoval et al., 1992; Hauser, 1993). In Kentucky the ECRB occurs in a restricted zone that narrows to the south and is likely completely buried in Tennessee (Fig. 9). We suggest that the ECRB was a zone of lithospheric weakness and that stresses imposed on the eastern edge of the Grenville lithosphere were transmitted westward and concentrated in this area, producing increased uplift or decreased subsidence along the overlying Cincinnati Arch, adjacent to the boundary between these two zones. This hypothesis explains the narrow width of this peripheral bulge (as manifested in the north-south alignment of shallowwater features and unconformities), and its occurrence in the same location for such a prolonged 
period during the Late Ordovician. A similar scenario, involving isostatic uplift of low-density Proterozoic sediments to the west of the Grenville basement was proposed for uplift along the Cincinnati Arch associated with Acadian (Silurian-Devonian) deformation (Rast and Goodman, 1995).

The stresses that produced the Cincinnati Arch in the Late Ordovician were likely responsible for the reactivation of structural features and formation of syndepositional faults and seismites in this area (Ettensohn et al., 2002). Similar features in the Upper Ordovician and Middle Silurian farther north along the Cincinnati Arch also are attributed to reactivation of basement faults along the boundary between the Grenville Front and EGRP/ECRB (Onasch and Kahle, 1991, 2002). Additionally, the long-distance transport of these Taconic orogenic stresses may have reactivated extensional faults of the underlying Reelfoot rift to produce the Sebree Trough (Kolata et al., 2001).

\section{Lateral Sedimentary Variation Along the Peripheral Bulge}

Inherited structural features can be reactivated and can affect sedimentologic and stratigraphic patterns in ways not predicted by stratigraphic models, such as alternating highs and lows along the axis of an arch (Diecchio, 1993; Holland and Patzkowsky, 1997; Bradley and Kidd, 1991). North-to-south variations in sedimentology and stratigraphy of the Upper Ordovician on the Cincinnati Arch, specifically from the Jessamine and Nashville domes indicate that this peripheral bulge did not behave uniformly throughout this period instead recording spatial and temporal variations in its response to coeval tectonism.

For instance, there is a change in depositional style from sequences M1-M4 to sequences M5-C6. Sequences M1-M4 are a thick succession of shallow subtidal to peritidal carbonates that 
were deposited on a homogeneous, flat to extremely gently-dipping ramp where facies changes across this platform were subtle. Peritidal carbonates rarely amalgamated into regional markers because there was likely a series of peritidal islands that evolved separately, rarely forming extensive regional units (Pratt and James, 1986).

After the M4 sequence, the ramp was more clearly differentiated, with grainstone shoals, peritidal facies and skeletal buildups arrayed as linear features along the Cincinnati Arch (Mackey, 1972; Holland and Patzkowsky, 1996, 1997; Pope and Read, 1997a; Ettensohn et al., 2002, 2004). Beginning with the $\mathrm{C} 1$ sequence, there was a significant change in sedimentation and stratigraphy from the Nashville and Jessamine Domes. The Jessamine Dome continued to be the locus of peritidal and shoal-water facies whereas the Nashville Dome has a dearth of these facies. There also is a change in the orientation of shoals from persistent north-south orientations to subtle east-west orientations. This $\mathrm{C} 1$ (Edenian) change in sedimentation and stratigraphy coincides with a structural reorganization on the Nashville Dome as evidenced by abrupt change in subsidence rates, followed by the erosional beveling of the $\mathrm{C} 2-\mathrm{C} 4$ sequences on the southern portion of the Nashville Dome. The abrupt change in subsidence rates on the Nashville Dome, but not on the Jessamine Dome, is most likely a reflection of the coeval northward migration of the orogenic load (i.e., Read, 1989; Rodgers, 1971). However, it is quite possible that the differential subsidence along this arch also may reflect sedimentary loading onto the continent from erosion of the coeval orogenic highland which is more pronounced to the north, or the reactivation of basement faults transverse to the arch controlling lateral subsidence patterns (Burgess and Gayer, 2000). 


\section{CONCLUSIONS}

1) The Cincinnati Arch was the peripheral bulge to the Blountian and Taconic phases of the Taconic Orogeny. The Cincinnati Arch, with the Nashville and Jessamine Domes in particular, were the consistent locus of peritidal, shoal, and buildup facies, as well as $3^{\text {rd }}$-order unconformities throughout the Late Ordovician and collectively indicate that this peripheral bulge was a stationary feature for 10-12 m.y. during this period. Subsidence analyses suggest that the Cincinnati Arch was either a slowly subsiding feature or that it was a slowly uplifting feature during a period of even greater net eustatic rise.

2) The static position of the Cincinnati Arch and Sebree Trough, as well as their narrow widths relative to the width of the coeval foreland basin are best explained by a lithospheric slab that contains lateral heterogeneities. The crustal boundary between the Grenville front and continental crust (EGRP) weakened by a subsequent rift event (ECRB) likely controls the flexural rigidity of the lithosphere in this area, serving as the locus of basement fault reactivation, syndepositional seismites and control of facies patterns along the Cincinnati Arch during the Taconic Orogeny.

3) Large-scale lateral variations in the facies along the Cincinnati Arch were likely caused by regional variations in subsidence produced by shifting centers of orogenic loading and syndepositional reactivation of basement faults.

\section{ACKNOWLEDGEMENTS}

Funding for Mike Pope's portion of this research provided by NSF EAR-9316057 (P.I. Fred Read). Acknowledgment is made to the Donors of the Petroleum Research Fund, administered by the American Chemical Society, for support of this research to Steven Holland. Mike Pope 
thanks Fred Read, Aus Al-Tawil, Taury Smith and Anna Balog for instructive discussions in forming many of the ideas put forth in this paper. Insightful reviews by Frank Ettensohn and Maya Elrick on an earlier version of this manuscript are greatly appreciated. 


\section{References}

Alberstadt, L.P., Walker, K.R., and Zurawski, R.P. (1974) Patch reefs in the Carters Limestone (Middle Ordovician) in Tennessee, and vertical zonation in Ordovician reefs. Geol. Soc. Am. Bull., 85, 1171-1182.

Allen, P.A., and Allen, J.R. (2005) Basin Analysis - Principles and Applications, 2nd edition. Blackwell Publishing, Malden, MA, 549 pp.

Ball, M.M. (1967) Carbonate sand bodies of Florida and the Bahamas. J. Sed. Petrol., 37, $556-591$.

Beaumont, C., Quinlan, G., and Hamilton, J. (1988) Orogeny and stratigraphy: Numerical models of the Paleozoic in the eastern interior of North America. Tectonics, 7, 389-416.

Black, D.F.B. (1986) Basement faulting in Kentucky. Proceedings of the Sixth International Conference on Basement Tectonics, 125-139.

Black, D.F.B., and Haney, D.C. (1975) Selected structural features and associated dolostone occurrences in the vicinity of the Kentucky River Fault System: Annual Field Conference, Geological Society of Kentucky, Kentucky Geological Survey, 27 pp.

Borella P.E., and Osborne, R.H. (1978) Late Middle and early Late Ordovician history of the Cincinnati Arch Province, central Kentucky to central Tennessee. Geol. Soc. Am. Bull., 89, 1559-1573.

Bradley, D.C., and Kidd, W.S.F. (1991) Flexural extensions of thee upper continental crust in collisional foredeeps. Geol. Soc. Am. Bull., 103, 1416-1438.

Brenchley, P.J., Marshall, J.D., Carden, G.A.F., Robertson, D.B.R., Long, D.G.F., Meidla, T., Hints, L., and Anderson, T.F. (1994) Bathymetric and isotopic evidence for a short-lived Late Ordovician glaciation in a greenhouse period: Geology, 22, 295-298. 
Brett, C.E., McLaughlin, P.I., Cornell, S.R., and Baird, G.C. (2004) Comparative sequence stratigraphy of two classic Upper Ordovician successions, Trenton Shelf (New YorkOntario) and Lexington Platform (Kentucky-Ohio): implications for eustasy and local tectonism in eastern Laurentia. Palaeogeogr., Palaeoclimatol., Palaeoecol., 210, 295-329.

Brookfield, M.E. (1988) A mid-Ordovician temperate carbonate shelf-The Black River and Trenton Limestone Groups of southern Ontario, Canada. Sed. Geol., 60, 137-154.

Browne, R.G. (1964) The coral horizons and stratigraphy of the Upper Richmond group in Kentucky west of the Cincinnati Arch. J. Paleontol., 38, 385-392.

Burgess, P.M., and Gayer, R.A. (2000) Late Carboniferous tectonic subsidence in South Wales: implications for Variscan basin evolution and tectonic history in SW Britain. J. Geol. Soc. London, 157, 93-104.

Cable, M.S., and Beardsley, R.W. (1984) Structural control on Late Cambrian and Early Ordovician carbonate sedimentation in eastern Kentucky. Am. J. Sci., 284, 797-824.

Crampton, S.L., and Allen, P.A. (1995) Recognition of forebulge unconformities associated with early stage foreland basin development: Example from the North Alpine foreland basin. AAPG Bull., 79, 1495-1514.

Cressman, E.R. (1973) Lithostratigraphy and depositional environments of the Lexington Limestone (Ordovician) of central Kentucky. US Geol. Surv. Prof. Pap. 768, 61 pp.

Cressman, E.R., and Noger, M.C. (1976) Tidal-flat carbonate environments in the High Bridge Group (Middle Ordovician) of central Kentucky. Kentucky Geol. Surv. Report of Investigations $18,15 \mathrm{pp}$.

Cuffey, R.J. (1998) The Maysville bryozoan reef mounds in the Grant Lake Limestone (Upper Ordovician) of north-central Kentucky. In: Sampling the Layer Cake That Isn't: The 
Stratigraphy and Paleontology of the Type-Cincinnatian (Eds. R.A. Davis, and R.J. Cuffey), Ohio Division of Geological Survey Guidebook 13, 38-44.

DeCelles, P.G., and Giles, K.A. (1996) Foreland Basin Systems. Basin Research, 8, 105123.

Dennison, J.M. (1976) Appalachian Queenston Delta related to eustatic sea-level drop accompanying Late Ordovician glaciation centered in Africa. In: The Ordovician System: Proceedings of a Palaeontological Association Symposium (Ed. M.G. Bassett), September, 1975, Cardiff, Wales, University of Wales and National Museum of Wales, 107-120.

Diecchio, R.J. (1993) Stratigraphic interpretation of the Ordovician of the Appalachian Basin and implications for Taconian flexural modeling. Tectonics, 12, 1410-1419.

Dorobek, S.M. (1995) Synorogenic carbonate Platforms and reefs in foreland basins: Controls on stratigraphic evolution and platform/reef morphology. In: Stratigraphic evolution of foreland basins (Eds. S.M. Dorobek, and G. Ross), SEPM Spec. Publ., 52, Tulsa, 127-146.

Dorobek, S.M., Reid, S.K., Elrick, M., Bond, G.C., and Kominz, M.A. (1991) Subsidence across the Antler foreland of Montana and Idaho: Tectonic versus eustatic effects. In: Sedimentary Modeling, Computer Simulations And Methods For Improved Parameter Definition (Eds. E.K. Franseen, W.L. Watney, and C.G. St. C. Kendall), Kansas Geol. Surv. Bull. 233, Lawrence, Kansas, 231-251.

Dorsch, J., Bambach, R.K., and Driese, S.K. (1993) Basin-rebound origin for the "Tuscarora Unconformity" in southwestern Virginia and its bearing on the nature of the Taconic orogeny. Am. J. Sci., 294, 237-255. 
Drake, A.A., Jr., Sinha, A.K., Laird, J., and Guy, R.E. (1989) The Taconic orogen. In: (Eds. R.D. Hatcher, Jr., W.A. Thomas, and G.W. Viele) The Appalachian-Ouachita orogen in the United States: Boulder, Colorado, Geol. Soc. Am., Geology of North America, F-2, 101-177.

Drahovzal, J.A., Harris, D.C., Wickstrom, L.H., Walker, D., Keith, B., and Furer, L.C. (1992) The east continental rift basin: A new discovery. Kentucky Geol. Surv. Spec. Publ. 18, Kentucky Geological Survey, Lexington, Kentucky, pp 25.

Ettensohn, F.R., Pashin, J.C., and Jacobs, G.W. (1986a) Characteristics of shallow-water, marine shelf silts and sands: Two Paleozoic examples from eastern Kentucky. Spring Program, Appalachian Basin Industrial Associates, 10, p. 197-207.

Ettensohn, F.R., Amig, B.C., Pashin, J.C., Greb, S.F., and others. (1986b) Paleoecology and paleoenvironments of the bryozoan-rich Sulphur Well Member, Lexington Limestone (Middle Ordovician), central Kentucky. Southeastern Geology, 26, 199-210.

Ettensohn, F. R. (1991) Flexural interpretation of relationships between Ordovician tectonism and stratigraphic sequences, central and southern Appalachians, USA. In: Advances in Ordovician geology (Eds. C.R. Barnes and S.H. Williams), Geol. Surv. Can. Pap., 90-9, $213-$ 224.

Ettensohn, F.R., Ed. (1992) Changing interpretations of Kentucky geology--layer-cake, facies, flexure, and eustacy. State of Ohio, Department of Natural Resources, Miscellaneous Report 5, pp. 184.

Ettensohn, F.R. (1994) Tectonic Control on Formation and Cyclicity of Major Appalachian Unconformities and Associated Stratigraphic Sequences. In: Tectonic and Eustatic Controls on Sedimentary Cycles (Eds J.M. Dennison and F.R. Ettensohn), SEPM Concepts in Sedimentology and Paleontology 4, 217-242. 
Ettensohn, F.R., Hohman, J.C., Kulp, M.A., and Rast, N.A. (2002) Evidence and implications of possible far-field responses to Taconic Orogeny: Middle-Late Ordovician Lexington Platform and Sebree Trough, east-central United States. Southeast. Geol., 41, 1-36.

Ettensohn, F.R., Kasl, J.M., and Stewart, A.K. (2004) Structural inversion and origin of a Late Ordovician (Trenton) carbonate buildup: evidence from the Tanglewood and Devils Hollow members, Lexington Limestone, central Kentucky (USA). Palaeogeogr., Palaeoclimatol., Palaeogeogr., 210, 249-266.

Flemings, P.B., and Jordan, T.E. (1989) A synthetic stratigraphic model of foreland basin development: J. Geophys. Res., 94, 3851-3866.

Flemings, P.B., and Jordan, T.E. (1990) Stratigraphic modeling of foreland basins: Interpreting thrust deformation and lithosphere rheology. Geology, 18, 430-434.

Galewsky, J. (1998) The dynamics of foreland basin carbonate platforms: tectonic and eustatic controls. Basin Res., 10, 409-416.

Galewsky, J., Silver, E.A., Gallup, C.D., Edwards, R.L., and Potts, D.C. (1996) Foredeep tectonics and carbonate platform dynamics in the Huon Gulf, Papua New Guinea. Geology, 24, 819-822.

Ginsburg, R.N. (1971) Landward movement of carbonate mud: new model for regressive cycles in carbonates. AAPG Bull., 55, 340.

Grotzinger, J., and Royden, L. (1990) Elastic strength of the Slave craton at 1.9 Ga and implications for the thermal evolution of the continents. Nature, 347, 64-66.

Gurnis, M. (1992a) Long-term controls on eustatic and epeirogenic motions by mantle convection. GSA Today, 2, 141, 144-145, 156-157. 
Gurnis, M. (1992b) Rapid continental subsidence following initiation and evolution of subduction. Science, 255, 1556-1558.

Gustadt, A.M. (1958) Upper Ordovician stratigraphy in eastern interior region: AAPG Bull., 42, 513-547.

Hatfield, C.B. (1968) Stratigraphy and paleoecology of the Saluda Formation (Cincinnatian) in Indiana, Ohio, and Kentucky. Geol. Soc. Am. Spec. Pap., 95, 1-34.

Hauser, E.C. (1993) Grenville foreland thrust hidden beneath the Eastern U.S. Midcontinent. Geology, 21, 61-64.

Haynes, J.T. (1994) The Ordovician Deicke and Millbrig K-Bentonite beds of the Cincinnati Arch and the southern Valley and Ridge Province. Geol. Soc. Am. Spec. Pap., 290, pp. 80.

Hohman, J.C. (1998) Depositional history of the Upper Ordovician Trenton Limestone, Lexington Limestone, Maquoketa Shale and equivalent lithologic units in the Illinois Basin; an application of carbonate and mixed carbonate-siliciclastic sequence stratigraphy. Unpublished Ph.D. Dissertation, University of Indiana, pp. 187.

Holland, S.M. (1993) Sequence stratigraphy of a carbonate-clastic ramp: The Cincinnatian Series (Upper Ordovician) in its type area: Geol. Soc. Am. Bull., 105, 306-322.

Holland, S.M., and Patzkowsky, M.E. (1996) Sequence stratigraphy and long-term paleoceanographic change in the Middle and Upper Ordovician of the eastern United States. In: Paleozoic Sequence Stratigraphy: Views from the North American Craton (Eds B.J. Witzke, G.A. Ludvigson, and J.D. Day), Boulder, Colorado, Geol. Soc. Am. Spec. Pap., 306, 117-129. Holland, S.M., and Patzkowsky, M.E. (1997) Distal Orogenic Effects on Peripheral Bulge Sedimentation: Middle and Upper Ordovician of the Nashville Dome: J. Sed. Res., 67, 250-263. 
Holland, S.M., and Patzkowsky, M.E. (1998) Sequence stratigraphy and relative sea-level history of the Middle and Upper Ordovician of the Nashville Dome, Tennessee. J. Sed. Res., 68, 684-699.

Horrell, M.A. (1981) Stratigraphy and depositional environments of the Oregon Formation (Middle Ordovician) of central Kentucky. Unpublished M.S. Thesis, University of Kentucky, Lexington, Kentucky, $121 \mathrm{pp}$.

Hrabar, S. V., Cressman, E.R., and Potter, P.E. (1971) Crossbedding of the Tanglewood Limestone Member of the Lexington Limestone (Ordovician) of the Blue Grass region of Kentucky. Brigham Young University Geology Studies, 18, 99-114.

Jacobi, R.D. (1981) Peripheral bulge - a causal mechanism for the Lower/Middle Ordovician disconformity along the western margin of the northern Appalachians. Earth and Planet. Sci. Lett., 56, 245-251.

Jacobs, G.W. (1986) Mixed siliciclastic-carbonate storm deposits in the Upper Ordovician of central Kentucky. Geol. Soc. Am. Program with Abstracts, 18, 228.

Jordan, T.E., and P.B. Flemings (1991) Large-scale stratigraphic architecture, eustatic variation, and unsteady tectonism: A theoretical evaluation. J. Geophys. Res., 96, 6681-6699.

Jewell, H.R., and Ettensohn, F.R. (2004) An ancient seismite response to Taconian farfield forces: The Cane Run Bed, Upper Ordovician (Trenton) Lexington Limestone, central Kentucky. J. Geodynamics, 37, 487-511.

Keith, B.D. (1988a) Regional facies of Upper Ordovician Series of eastern North America: In: The Trenton Group (Upper Ordovician Series) of eastern North America (Ed B.D. Keith), AAPG Studies in Geology 29, 1-16. 
Keith, B.D. (1988b) The Trenton Group (Upper Ordovician Series) of eastern North America; deposition, diagenesis, and petroleum. In: The Trenton Group (Upper Ordovician Series) of eastern North America (Ed B.D. Keith), AAPG Studies in Geology 29, p. 267-276.

Kolata, D.R., Huff, W.D., and Bergström, S.M. (1996) Ordovician K-bentonites of eastern North America. Geol. Soc. Am. Spec. Pub. 313, 84 pp.

Kolata, D.R., Huff, W.D., and Bergström, S.M. (1998) Nature and significance of unconformities associated with the Middle Ordovician Hagan K-bentonite complex in the North American midcontinent. Geol. Soc. Am. Bull., 110, 723-739.

Kolata, D.R., Huff, W.D., and Bergström, S.M. (2001) The Ordovician Sebree Trough: an oceanic passage to the midcontinent United States. Geol. Soc. Am. Bull., 113, 1067-1078.

Kreisa, R.D. (1981) Storm-generated sedimentary structures in subtidal marine facies with examples from the Middle and Upper Ordovician of southwestern Virginia: J. Sed. Petrol., 51, 823-848.

Kuhnhenn, G.L., Grabowski, G.J., Jr., and Dever, G.R., Jr. (1981) Paleoenvironmental interpretation of the Middle Ordovician High Bridge Group in central Kentucky. In: Stratigraphy, Sedimentology (Ed T.G. Roberts), Geol. Soc. Am. Cincinnati Meeting Field Trip Guidebooks, 1-30.

Kuhnhenn, G.L., and Haney, D.C. (1986) The Middle Ordovician High Bridge Group and Kentucky River Fault System in central Kentucky. In: Centennial Field Guide, Southeastern Section of the Geol. Soc. Am. (Ed T.L. Neathery), 6, 25-29.

Kulp, M.A. (1995) Paleoenvironmental interpretation of the Brannon Member, MiddleUpper Ordovician Lexington Limestone, central Bluegrass region of Kentucky. Unpublished M.S. thesis, University of Kentucky, Lexington, Kentucky, 222 pp. 
Kulp, M.A., and Ettensohn, F.R. (1995) Paleoenvironmental interpretation of the Brannon Member: Evidence of synsedimentary tectonism in the Middle Ordovician Lexington Limestone, central Kentucky. Geol. Soc. Am. Abstracts with Programs, Southeastern Section, 27, 67.

Lash, G.G. (1988) Middle and Late Ordovician shelf activation and foredeep evolution, central Appalachian Orogen. In: The Trenton Group (Upper Ordovician Series) of eastern North America (Ed B.D. Keith), AAPG Studies in Geology 29, 37-53.

Lavoie, D. (1995) A Late Ordovician high-energy temperate-water carbonate ramp, southern Quebec, Canada: implications for Late Ordovician oceanography. Sedimentology, 42, 95-116.

Mackey, R.T. (1972) Lithostratigraphy and depositional environment of the Perryville Limestone and related members of the Lower Lexington Limestone (Ordovician) of southcentral Kentucky. Unpublished Masters thesis, University of Kentucky, Lexington, Kentucky, 76 pp.

MacQuown, W.C., Jr., Kuhnhenn, G.L., Shepard, R.G., and Gooding, P.G. (1984) Fieldtrip 6, Lithostratigraphy and depositional environments of the Middle Ordovician limestones in central Kentucky. In: Fieldtrip Guidebooks for the Southeastern/North-central section Geological Society of America Meeting (Eds N. Rast and H.B. Hay), University of Kentucky, Lexington, Kentucky, p. 66-83.

McBride, E.F. (1962) Flysch and associated beds of the Martinsburg Formation (Ordovician), central Appalachians. J. Sed. Petrol., 32, 39-91.

McLaughlin, P.I., and Brett, C.E. (2004) Eustatic and tectonic control of marine seismites; examples from the Upper Ordovician of Kentucky, USA. Sed. Geol., 168, 165-192.

McLaughlin, P.I., Brett, C.E., Taha McLaughlin, S.L., and Cornell, S.R. (2004) Highresolution sequence stratigraphy of a mixed carbonate-siliciclastic, cratonic ramp (Upper 
Ordovician; Kentucky-Ohio, USA): insights into the relative influence of eustasy and tectonics through analysis of facies gradients. Palaeogeogr. Palaeoclimatol. Palaeoecol., 210, 267-294.

Mitrovica, J. X., Beaumont, C., and Jarvis, G.T. (1989) Tilting of continental interiors by the dynamical effects of subduction. Tectonics, 8, 1079-1094.

Mussman, W.J., and Read, J.F. (1986) Sedimentology and development of a passive- to convergent-margin unconformity: Middle Ordovician Knox unconformity: Geol. Soc. Am. Bull., 97, 282-295.

Nádai, A., 1963, Theory of flow and fracture of solids. McGraw Hill Book Co., New York, $411 \mathrm{pp}$.

Onasch, C.M., and Kahle, C.F. (1991) Recurrent tectonics in a cratonic setting: An example from northwestern Ohio. Geol. Soc. Am. Bull., 103, 1259-1269.

Onasch, C.M., and Kahle, C.F. (2002) Seismically induced soft-sediment deformation in some Silurian carbonates, eastern U.S. Midcontinent. In: Ancient Seismites (Eds F.R. Ettensohn and N. Rast, and C.E. Brett), Geol. Soc. Am. Spec. Pap. 359,165-176.

Patzkowsky, M.E., and Holland, S.M. (1993) Biotic response to a Middle Ordovician paleoceanographic event in eastern North America. Geology, 21, 619-622.

Patzkowsky, M.E., and Holland, S.M. (1999) Biofacies replacement in a sequence stratigraphic framework: Middle and Upper Ordovician of the Nashville Dome, Tennessee, USA. Palaios, 14, 301-323.

Pope, M.C., and Read, J. F. (1995) Late Ordovician Tanglewood Bank: a highly compartmentalized buildup reflecting tectonics and moderate amplitude eustasy on the Cincinnati Arch. Geol. Soc. Am. Abstracts with Programs, 27, A450. 
Pope, M.C., Read, J.F., Bambach, R.K., and Hofmann, H.J. (1997) Late Middle to Late Ordovician seismites of Kentucky, Southwestern Ohio and Virginia: Sedimentary recorders of Earthquakes in the Appalachian Basin. Geol. Soc. Am. Bull., 109, 489-503.

Pope, M.C., and Read, J.F. (1997a) High-frequency cyclicity of the Lexington Limestone (Middle Ordovician), a cool-water carbonate clastic ramp in an active foreland basin. In: CoolWater Carbonates (Eds N.P. James and J.P. Clarke), SEPM Spec. Publ. 56, 411-429.

Pope, M.C., and Read, J.F. (1997b) High-resolution surface and subsurface sequence stratigraphy of Middle to Late Ordovician (Late Mohawkian to Cincinnatian) foreland basin rocks, Kentucky and Virginia. AAPG Bull., 81, 1866-1893.

Pope, M.C., and Read, J.F. (1998) Ordovician metre-scale cycles: Implications for Ordovician climate and eustatic fluctuations in the central Appalachian Basin, USA. Palaeoclimatol. Palaeogeogr. Palaeoecol., 138, 27-42.

Pratt, B.R., and James, N.P. (1986) The tidal flat islands model of peritidal shallowingupward sequences: St. George Group, western Newfoundland. Sedimentology, 33, 313-345.

Quinlan, G. M., and Beaumont, C. (1984) Appalachian thrusting, lithospheric flexure, and the Paleozoic stratigraphy of the eastern interior of North America. Can. J. Earth Sci., 21, 973996.

Rast, N., and Goodman, P.T. (1995) Tectonic and sedimentary consequences of Late Proterozoic and Early and Mid-Paleozoic overthrusting in Kentucky and adjacent states. Northeastern Geology and Environmental Sciences, 17, 2-9.

Read, J.F. (1980) Carbonate ramp-to-basin transitions and foreland basin evolution, Middle Ordovician, Virginia Appalachians. AAPG Bull., 64, 1575-1612. 
Read, J.F. (1989) Controls on evolution of Cambrian-Ordovician passive margin, U.S. Appalachians. In: Controls on carbonate platform and basin development (Eds P.D. Crevello, J.L. Wilson, J.F. Sarg, and J.F. Read), SEPM Spec. Publ. 44, p. 147-165.

Riding, R. (2004) Solenopora is a chaetetid sponge, not an alga. Palaeontology, 47, 117-122.

Rodgers, J. (1971) The Taconic orogeny: Geol. Soc. Am. Bull., 82, 1141-1178.

Ruppel, S.C., and Walker, K.R. (1984) Petrology and depositional history of a Middle Ordovician carbonate platform; Chickamauga Group, northeastern Tennessee. Geol. Soc. Am. Bull., 95, 568-583.

Scharpf, C.D. (1990) Stratigraphy and associated faunas of the Middle Ordovician (Rocklandian) Millbrig K-bentonite in central Kentucky. Unpublished Masters thesis, University of Cincinnati, Cincinnati, Ohio. 280 pp.

Shanmugam, G., and Lash, G.G. (1982) Analogous tectonic evolution of the Ordovician foredeeps, southern and central Appalachians. Geology, 10, 562-566.

Shanmugam, G., and Walker, K.R. (1980) Sedimentation, subsidence and evolution of a foredeep basin in the Middle Ordovician, southern Appalachians. Am. J. Sci., 280, 479-496.

Shanmugam, G., and Walker, K.R. (1982) Anatomy of the Middle Ordovician Sevier Shale Basin, eastern Tennessee. Sedimentology, 34, 315-337.

Simmons, G.C., and Oliver, W.A., Jr. (1967) Otter Creek Coral Bed and its fauna, eastcentral Kentucky. U.S. Geol. Surv. Bull., 1244-F, 1-13.

Sinclair, H.D., and Allen, P.A. (1992) Vertical vs. horizontal motions in the Alpine orogenic wedge: stratigraphic response in the foreland basin. Basin Res., 4, 215-232. 
Sinclair, H.D., Coakley, B.J., Allen, P.A., and Watts, A.B. (1991) Simulation of foreland basin stratigraphy using a diffusion model of mountain belt uplift and erosion: an example from the central Alps, Switzerland, Tectonics, 10, 599-620.

Sloss, L.L. (1963) Sequences in the cratonic interior of North America: Geol. Soc. Am. Bull., 74, 93-113.

Sweet, W.C. (1984) Graphic correlation of upper Middle and Upper Ordovician rocks, North American Midcontinent Province, U.S.A. In: Aspects of the Ordovician System: Palaeontological Contributions form the University of Oslo (Ed D.L. Bruton), Universitetsforlaget. Oslo, University of Oslo, 23-35.

Tankard, A.J. (1986) On the depositional response to thrusting and lithospheric flexure: examples from the Appalachian and Rocky Mountain basins. In: Foreland Basins (Eds P.A. Allen and P. Homewood), Int. Assoc. Sedimentol. Spec. Publ. 8, Blackwell Publications, Oxford, 369-392.

Turcotte, D.L., and Schubert, G. (2002) Geodynamics (2nd edition). Cambridge University Press. 456 pp.

Van Schmus, W. R., Bickford, M.E., Anderson, J.L., Bender, E.E., Anderson, R.R., Bauer, P.W., Robertson, J.M., Bowring, S.A., Condie-K.C., Denison, R.E., Gilbert, M.C., Grambling, J.A., Mawer, C.K, Shearer, C.K., Hinze, W.J., Karlstrom, K.E., Kisvarsanyi, E.B., Lidiak, E.G., Reed, J.C. Jr., Sims, P.K., Tweto, O., Silver, L.T.,Treves, S.B., Williams, M.L. Wooden, J.L. (1993) Transcontinental Proterozoic provinces. In: Precambrian; conterminous U.S., (Eds J.C. Reed, Jr., M.E. Bickford, R.S. Houston, P. L. Link, D.W. Rankin, P.K. Sims, and W. R. Van Schmus), The Geology of North America, C-2, Geol. Soc. Am.. Boulder, CO, United States, 171-334. 
Walker, K.R., and Laporte, L.F. (1970) Congruent fossil communities from Ordovician and Devonian carbonates of New York. J. Paleontol., 44, 928-944.

Waschbusch, P.J., and Royden, L.H. (1992a) Spatial and temporal evolution of foredeep basins: lateral strength variations and inelastic yielding in continental lithosphere. Basin Res., 4, $179-196$.

Waschbusch, P.J., and Royden, L.H. (1992b) Episodicity in foredeep basins. Geology, 20, 915-918.

Weir, G.W., Peterson, W.L., and Swadley, W.C. (1984) Lithostratigraphy of Upper Ordovician strata exposed in Kentucky. US Geol. Surv. Prof. Pap. 1151-E, 121 pp.

Weiss, M.P., Edwards, W.R., Norman, C.W., and Sharp, E.R. (1965) The American Upper Ordovician standard. VII. Stratigraphy and petrology of the Cynthiana and Eden Formations of the Ohio Valley. Geol. Soc. Am. Spec. Pap. 81, 76 pp.

Wilson, C.W., Jr. (1949) Pre-Chattanooga stratigraphy in central Tennessee. Tennessee Division of Geology, Bulletin 56, 1-407.

Wilson, C.W., Jr. (1962) Stratigraphy and geologic history of Middle Ordovician rocks of central Tennessee. Geol. Soc. Am. Bull., 73, 481-504.

Wilson, C.W., Jr., and Stearns, R.G. (1963) Quantitative analysis of Ordovician and younger structural development of Nashville Dome, Tennessee. AAPG Bull., 47, 823-832.

Wolcott, D.E., Cressman, E.R., and Connor, J.J. (1972) Trend-surface analysis of the thickness of the High Bridge Group (Middle Ordovician) of central Kentucky and its bearing on the nature of the post-Knox unconformity. US Geol. Surv. Prof. Pap. 800, B25-B33. 


\section{Figure Captions}

1. Cross-sections of foreland basin evolution for a continuous elastic plate $(\mathrm{A}-\mathrm{C}), \mathrm{a}$ continuous viscoelastic plate (A-D), and an elastic plate with lithospheric heterogeneities (E) plotted next to their respective Wheeler diagrams. Areas of non-deposition or erosion over a subaerially exposed peripheral bulge indicated in black on the Wheeler diagrams.

2. Map of study area, showing outcrop belts of Upper Ordovician rocks in gray, as well as the locations of principal structural features in the region. Contours of Upper Ordovician sediment thickness in the Martinsburg and Sevier basins are indicated.

3. Lithostratigraphic units and sequence stratigraphic architecture of Upper Ordovician strata on the Cincinnati Arch, following nomenclature of Holland and Patzkowsky (1996, 1998). Age is based on a calibration of the conodont-based graphic correlation of Sweet (1984); see Holland and Patzkowsky (1998) for details of age calibration.

4. Map of Blountian features along the Cincinnati Arch. The distribution of the Oregon Formation indicates that it formed along a topographic high (Kuhnhenn et al., 1981; Wolcott et al., 1972). The Millbrig K-bentonite is eroded over much of the Jessamine and Nashville Domes (adapted from Scharpf, 1990; Haynes, 1994; Kolata et al., 1998) suggesting these areas were topographically high or exposed during deposition of this widespread ash bed.

5. Regional north-south cross-section of M5-C5 strata on the Cincinnati Arch. Initials are locations of measured sections, see Pope and Read (1997b) and Holland and Patzkowsky (1996, 
1997, 1998) for individual sections. Note how sedimentation and stratigraphy in M5 and M6 are similar but there is a significant change in sedimentation and stratigraphy during C1-C5.

6. Map showing distribution of facies during the M5 and M6 sequences along the Cincinnati Arch. Note restriction of peritidal and shoal facies to a stable belt during this interval.

7. Map of shallow water features of the C2-C5 sequences, including silty peritidal dolomite and the tidally influenced Garrard Siltstone, both of which were deposited along the Cincinnati Arch.

8. Accommodation histories generated by backstripping analysis of sections from the northern Nashville Dome and from the central Jessamine Dome. Long-term patterns are thought to reflect primarily subsidence histories, whereas short-term patterns $(<1$ m.y.) are thought to reflect eustasy.

9. Map showing the relation between the Cincinnati Arch and the boundary between Grenville crust and the Eastern Granite-Rhyolite Province (EGRP) and the East Continent Rift Basin (ECRB). Adapted from Drazhoval et al. (1992). The Cincinnati Arch lies just west of this boundary and it is suggested that its relatively fixed position and narrow width are due to uplift or decreased subsidence within this zone of weak lithosphere. In this scenario, orogenic stresses generated to the east were repeatedly transmitted to this zone of weak lithosphere, which responded by syndepositional faulting and resisting subsidence. 

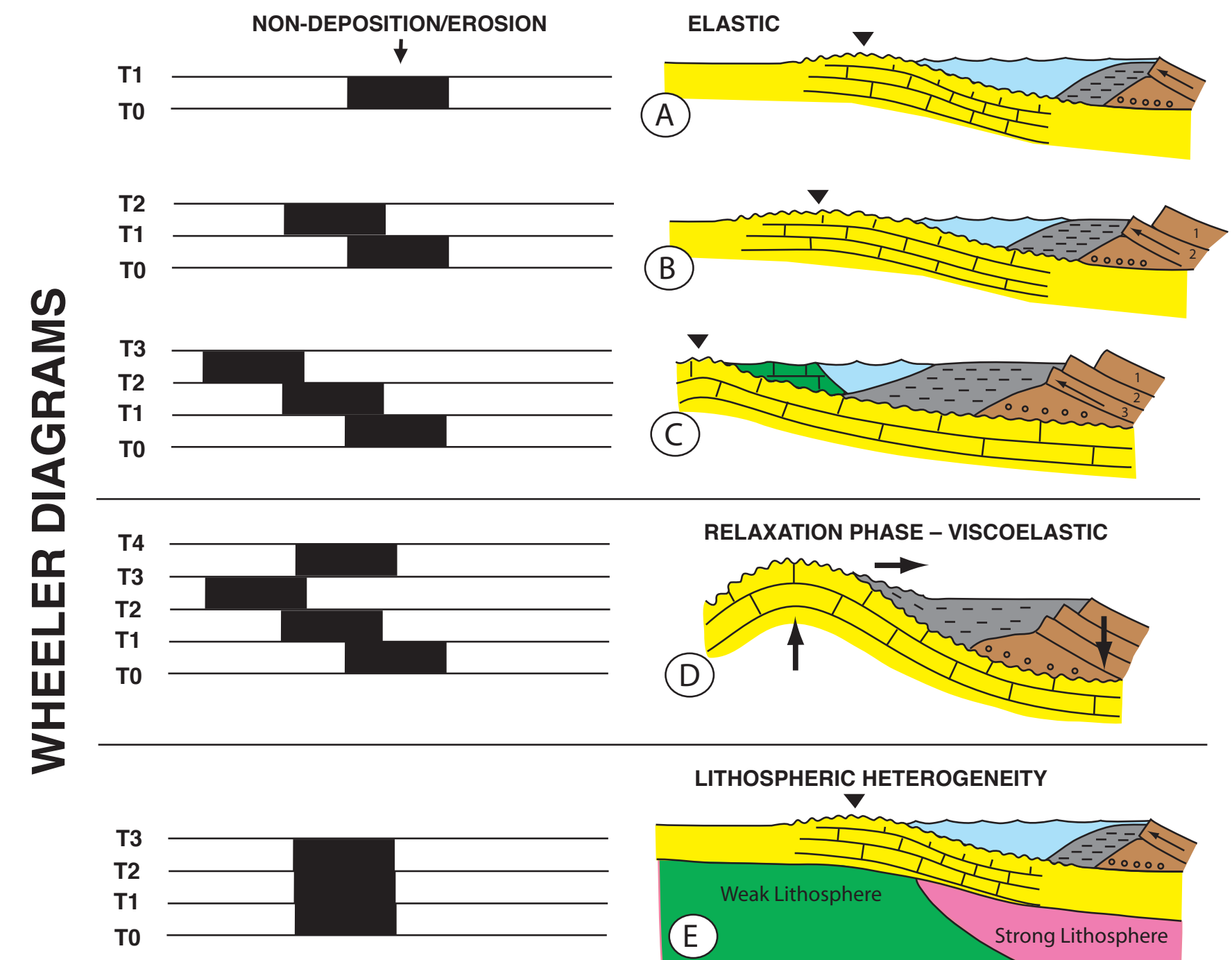

RELAXATION PHASE - VISCOELASTIC
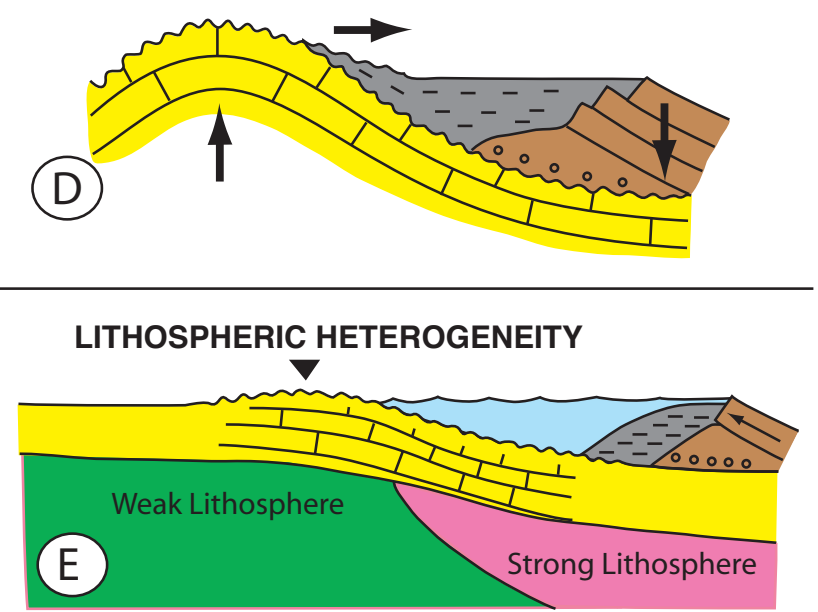

Pope et al., Fig. 1 


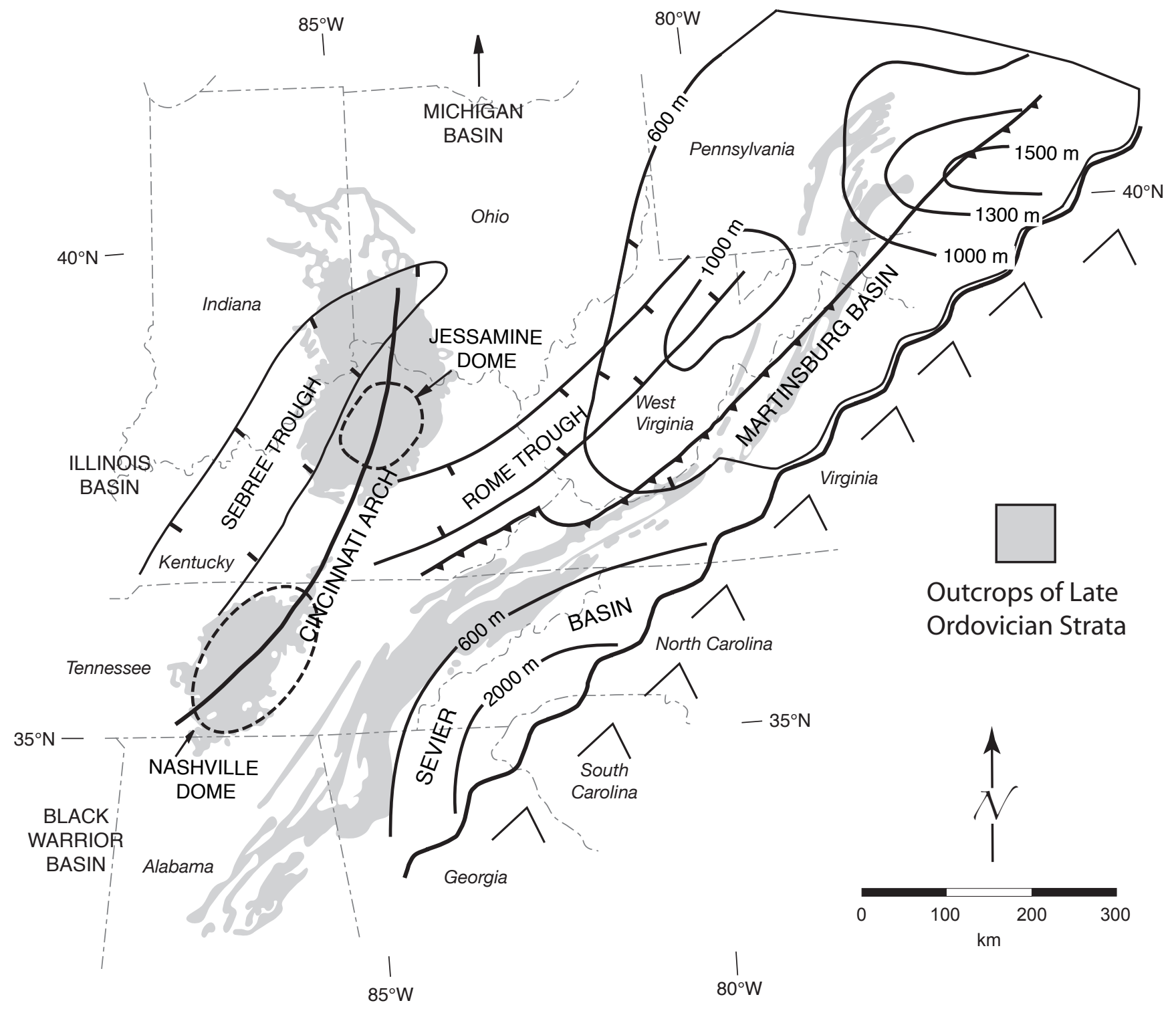

Pope et al., Fig. 2 

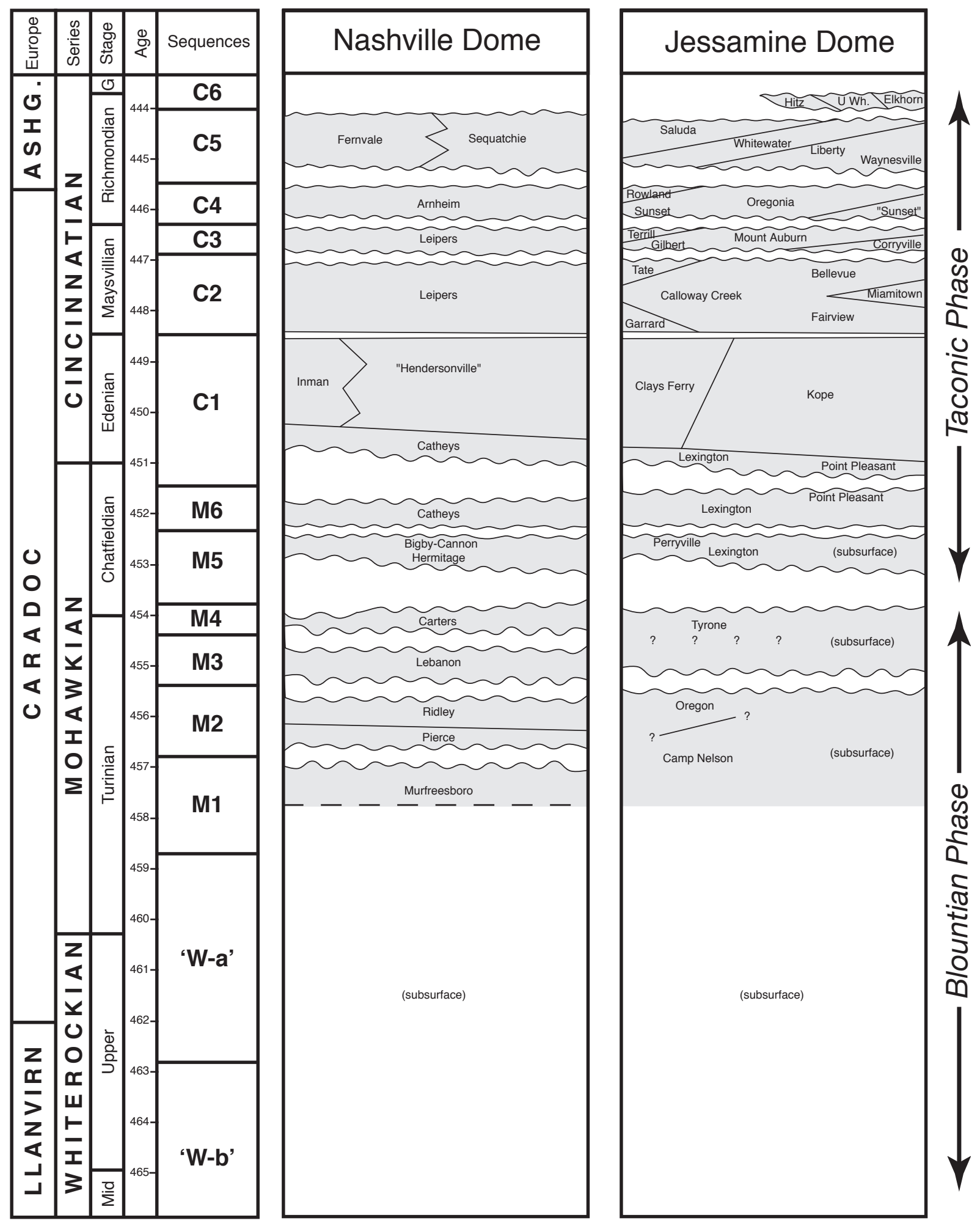


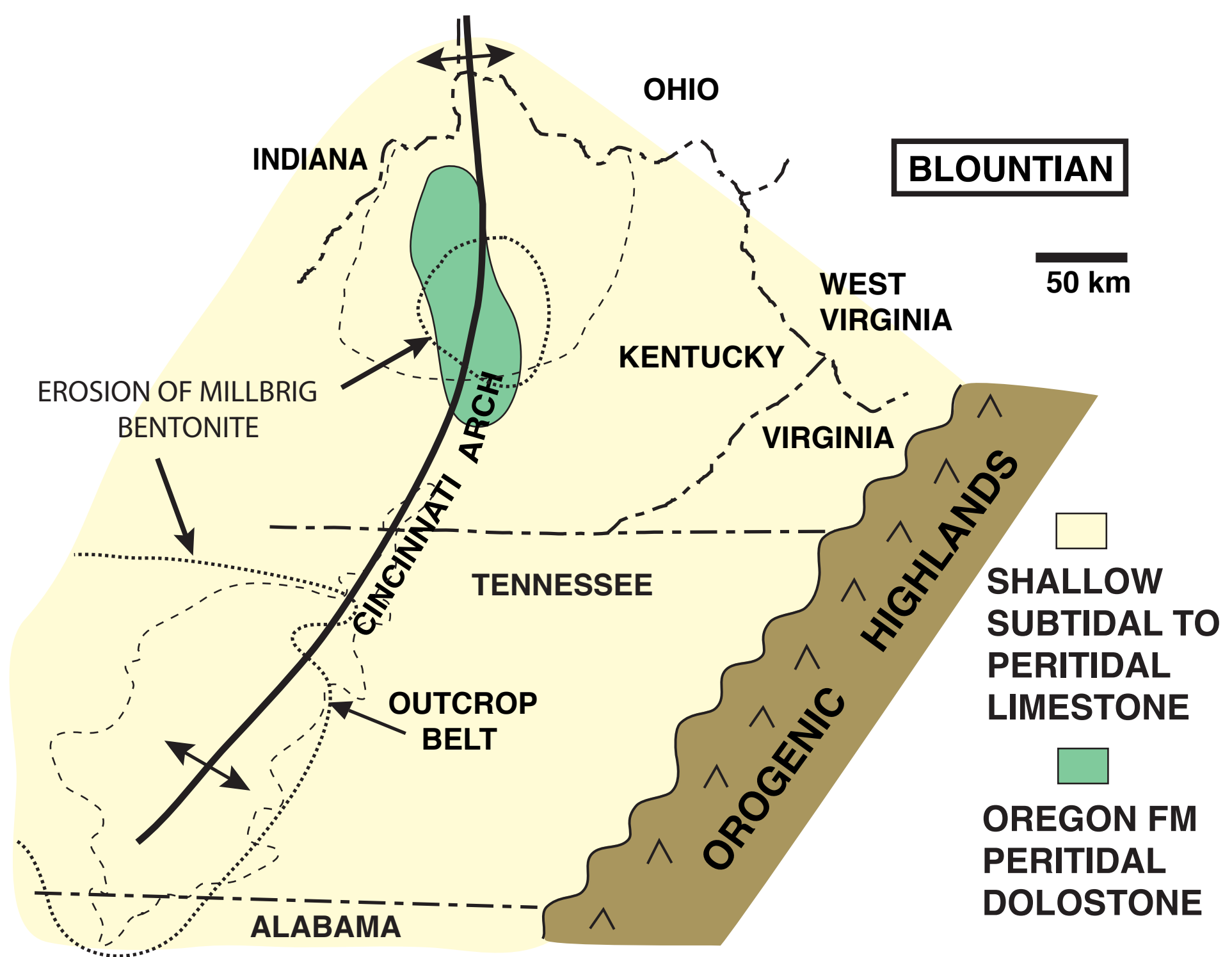




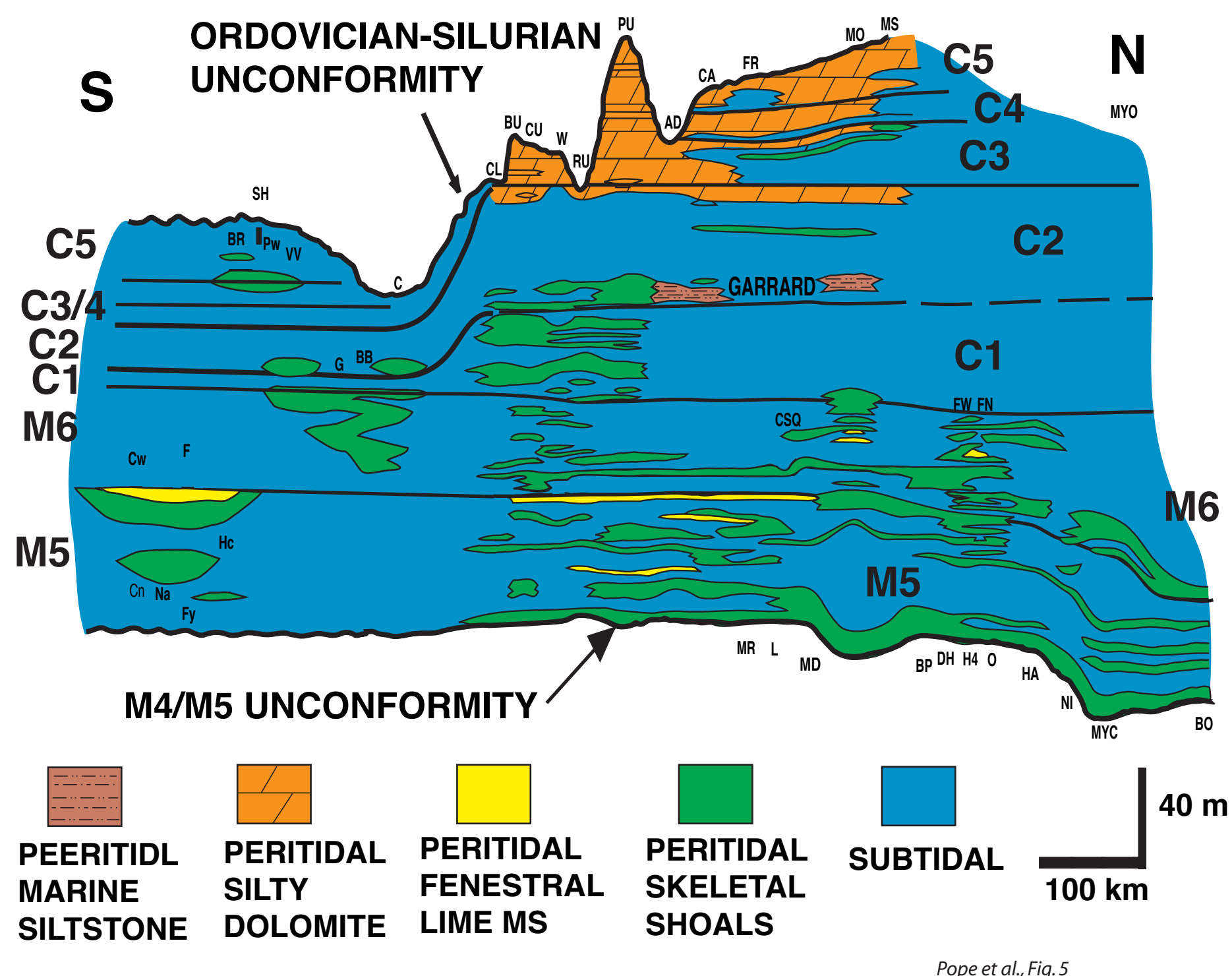




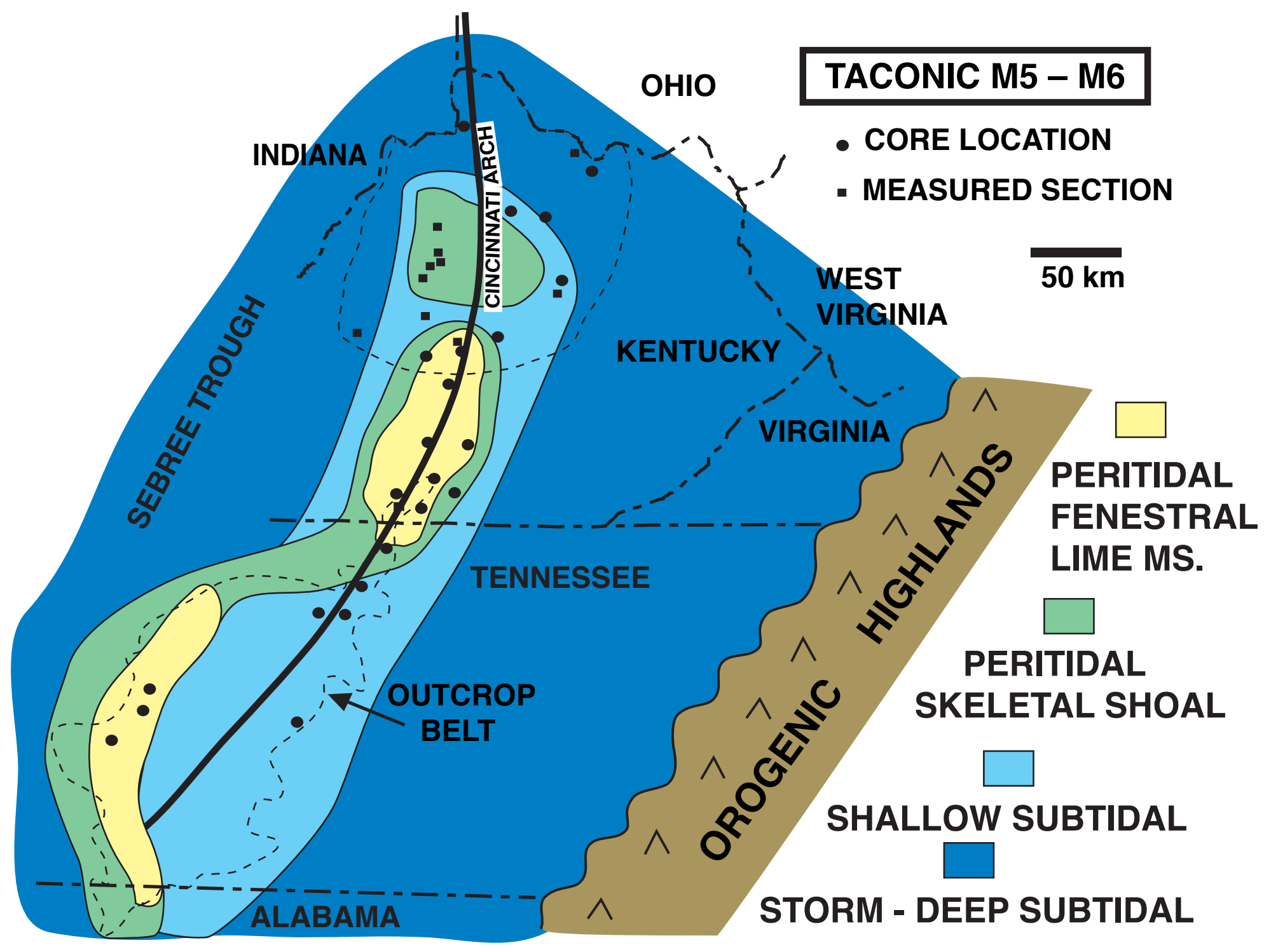




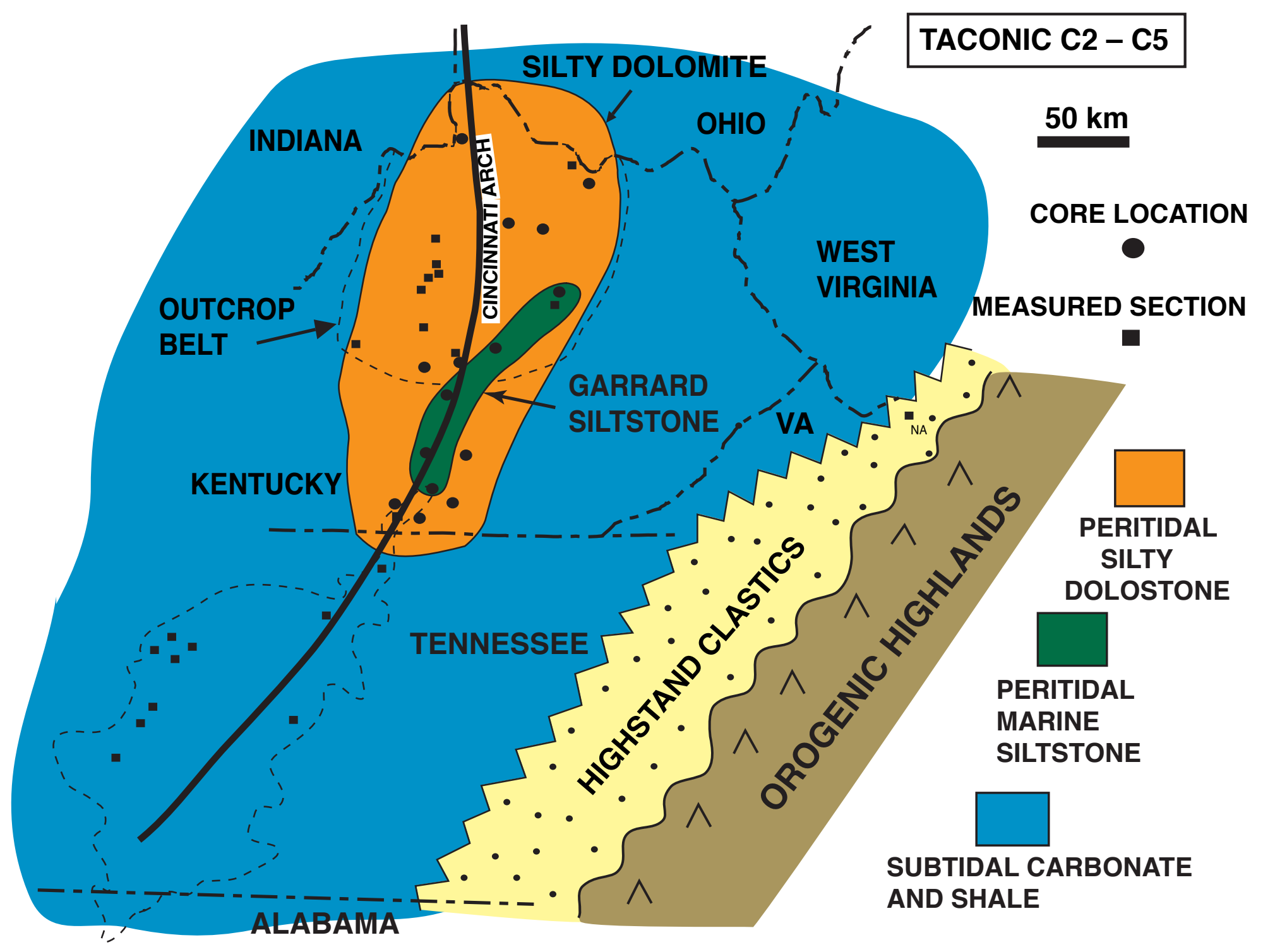

Pope et al., Fig. 7 


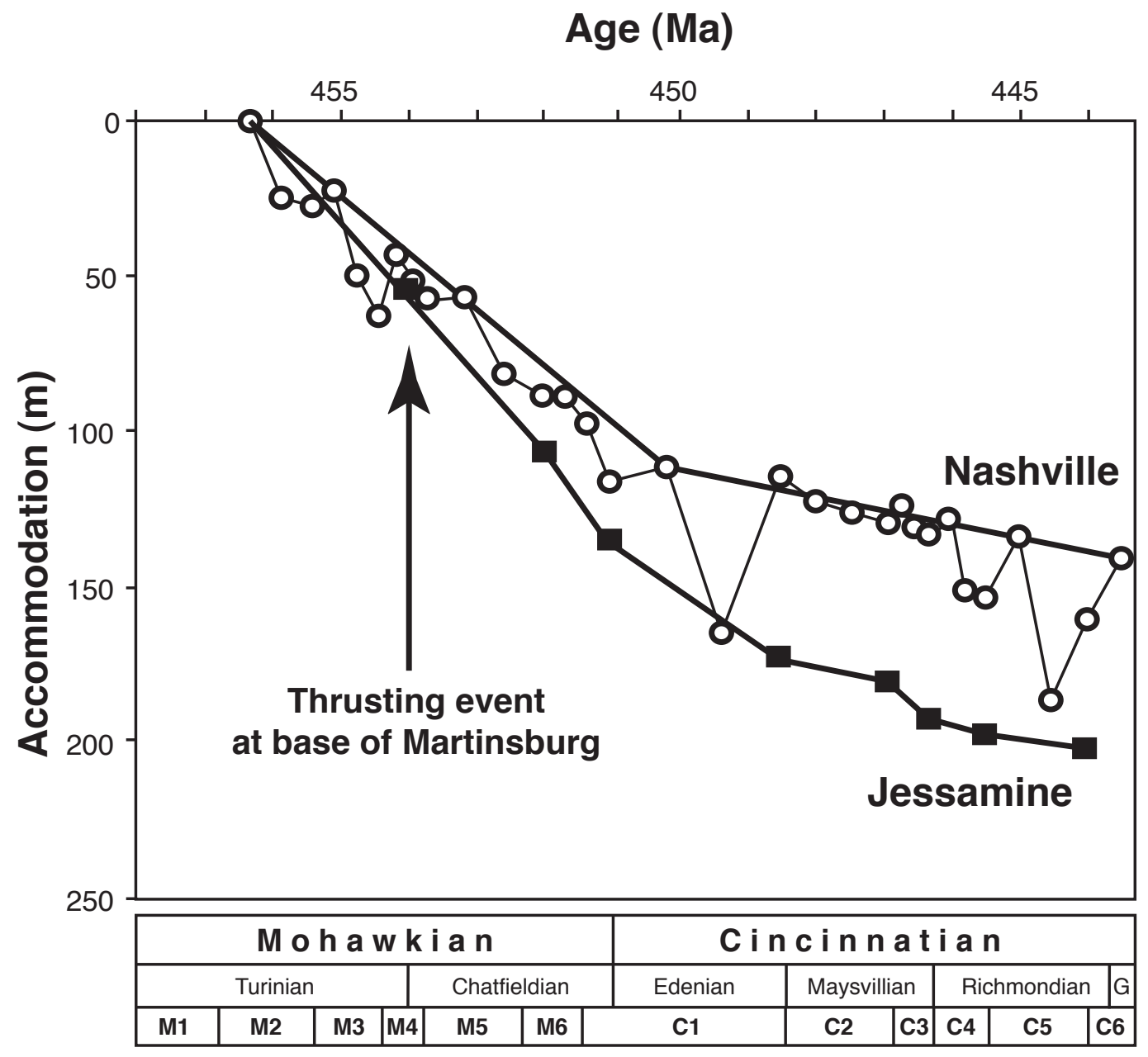

Pope et al. Fig. 8 


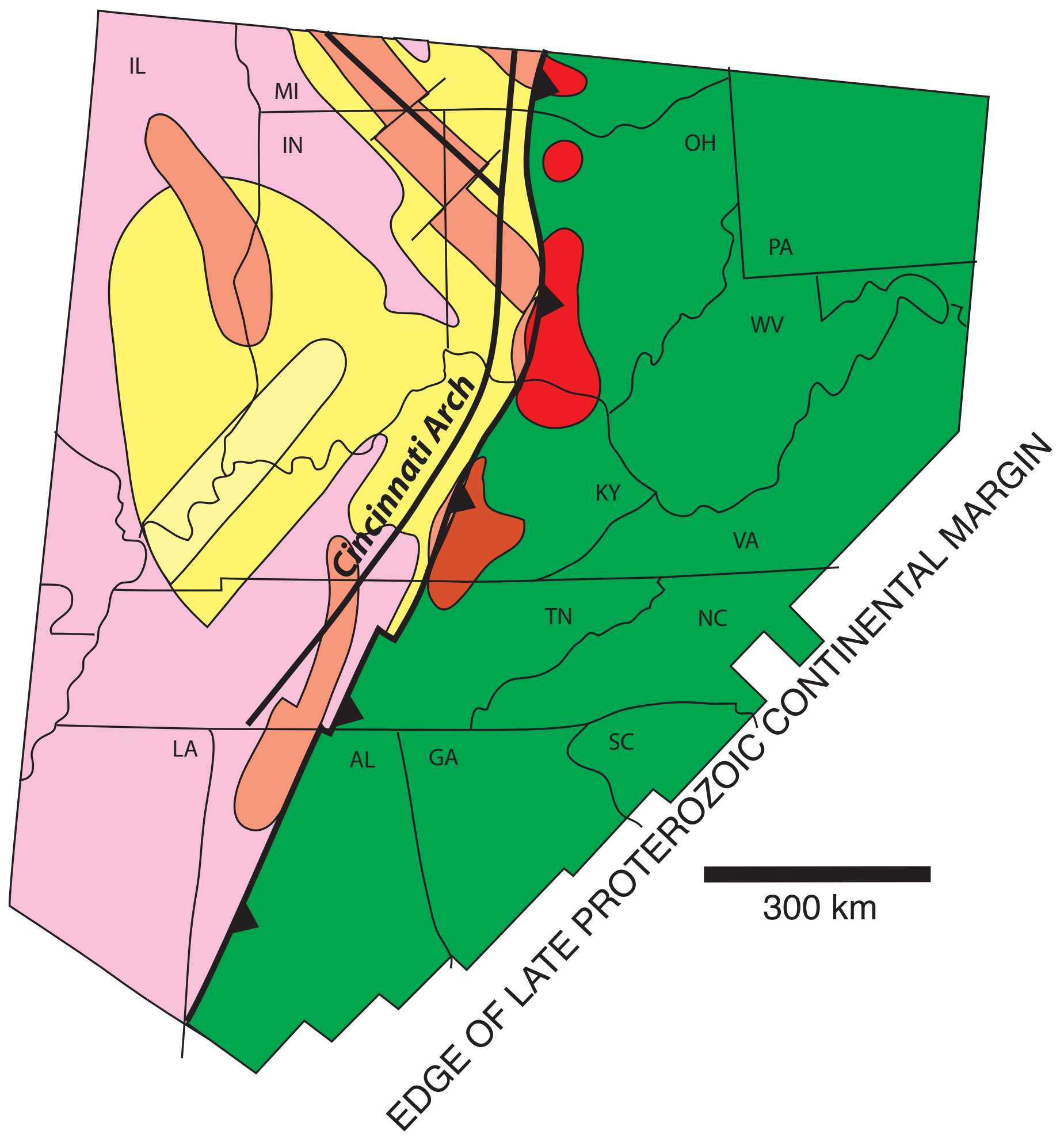

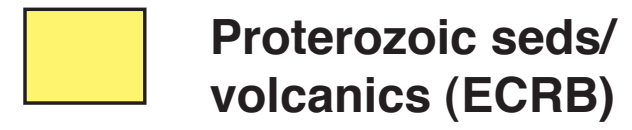

Reelfoot Rift

Eastern Granite-Rhyolite Province (EGRP)

\section{Grenville Province}

Basaltic Rift Zone

Basaltic Rift Zone (buried) 